\title{
EFFECTS OF ALPHA INTERFERON ON THE LYMPHOID TISSUE OF THE SPLEEN IN YOUNG ADULT AND SENILE MICE
}

\author{
Shahira Youssef \\ Anatomy Department, Faculty of Medicine, Ain Shams University
}

\section{INTRODUCTION}

Interferons are natural cytokines with a variety of biological effects including antiviral, antiproliferative, antifibrogenic and antianiogenic properties (Hiramatsu et al., 1995; Muriel 1996; Kim et al., 2000). Interferons inhibit transcription and translation of a number of RNA and DNA viruses as well as the growth and proliferation of a variety of cells (Theocharis et al., 1997). Furthermore, interferons could alleviate fibrosis and inflammation (Mazzoran et al., 1998). The two main members of interferon 1 family namely interferon alpha and beta have gained special valuc as they proved to be successful in treatment of chronic viral infections, myoproliferative disorders and autoimmune discases. Interferon alpha is the only available effective trcatment for chronic viral hepatitis C (Kaserer et al., 1998; Duchatelle et al.,1998). It is also used in chronic hepatitis B, chronic non $A$ non B hepatitis and chronic delta hepatitis (Yoo et al., 1990; Kleiner et al., 1993; Manabe et al., 1993). Moreover, it is uscful in reversing liver damage induced by biliary obstruction (Moreno \& Muriel 1995). Through its immunomodulatory activity, interferons decrease the incidence of severity of precancerous lesions (Merle et al., 1997). It is also efficacious in treatment of pancreatic tumors. renal cell carcinoma. chronic myelogeneous leukemia, hairy cell lcukemia, cutaneous melanoma and polycythemia (Lamers 1990; Baer et al., 1992; Toliou et al., 1996; Bose et al., 1997; Elliot \& Tefferi 1997; Otely \& Zitelli 2000).

Despite of the variation in the etiology of the diseases treated by interferons and the different types of immune responses thought to be required to control them, interferon $I$ is able to provide effective therapy. It is likely that interferon induced marked changes in the immune status which depend on its ability to influence the 
differentiation of $\mathrm{B}$ and $\mathrm{T}$ lymphocytes and increase lymphocyte adhesion to endothelial cells by up-rcgulation of adhesion molccules (Steinger \& Van Der Meide, 1993). Among its other immunological effects, interferons provoked activation and proliferation of monocytes, macrophages, cytotoxic $T$ cells and natural killer cells eliciting long lasting tumor specific immunity (Eguchi et al., 2003). These changes were accompanicd by augmented expression of surface activation markers on the effecter cells (Suzuki et al., 2002).

Reviewing the literature demonstrated that alpha interferons inhibited the spontaneous apoptosis of primary B lymphocytes and promoted survival of peripheral B lymphocytes enhancing immune responses (Ruuth et al., 2001). Few data, however are available about the morphological changes induced by alpha interferon. the different phases of cell cycle and DNA content in lymphocyte populations of the different lymphoid organs.

On the other hand, several factors were identified to influence and limit the response to interferon therapy negatively. Among these factors are the long duration of the disease, the elevated histological indexes, the high levels of the virus, alcoholism, and the high age of the paticnts (Ono et al., 1996; Kaserer et al., 1998). Aging in particular is associated with dysfunction of immune system and detcrioration of immunity. Dramatic decline of pre- $B$ cells number and reduced proliferative capacity of both $T$ and $B$ lymphocytes as well as the germinal centers are common consecutive changes of aging (Johnson et al., 2002; Blasco, 2002). Moreover, the process of aging has been proposed to be associated with gradual accumulation of destructive products of endogenously generated free radicals. The consequences of endogenously generated radicals are usually estimated in terms of damage to macromolecules most notably lipids, proteins and DNA (El-Sokkary et al., 2003).

Hence, it becomes the aim of the present work to clarify the senile changes that are likely to occur in the spleen of mice. Furthermore, the present study aimed at investigating and comparing the morphological changes, the phases of the cell cycle and the DNA content in adult and senile splecn following interferon alpha administration. It is believed that the spleen is a major repository of immune cells in the body that can reflect any changes in the immune status. The evaluation of immunological status before initiation of treatment might be of great clinical importance as it has a major influence on the effects and outcome of interferon therapy. 


\section{MATERIAL AND METHODS}

Mice :

Forty CBA male mice locally bred at the animal house of the Research Unit and Bilharzial Research Center of Faculty of Medicine, Ain Shamus University were used in the present study. Adult mice aged $3-4$ months and weighed $25-30$ grams. Senile mice aged 18 - 24 months and weighed $30-35$ grams. Animals were housed in separate cages, fed on standard mice diet and allowed water ad-libitum.

\section{Interferon :}

Alpha interferon was available as vials of "Interon $A$, injection" (Schering Phough USA). Each vial contained 3 million IU of intcrleron Alpha $2 b$. Vials werc reconstituted with $1 \mathrm{ml}$ of sterile water and stored at temperature $2-8 \mathrm{c}^{\circ}$, each mice received $3.3 \times 10^{4}$ lu $/ \mathrm{kg} \mathrm{B.W}$. Interferon was diluted to the appropriate concentration in sterile water of sufficient volume for a single dose for cach group of mice. The dose and regimen given were equivalent and similar to human therapeutic dose (Theocharis et al., 1997). At the beginning of the experiment mice were divided into four groups as follows :

\section{Group I :}

It included five adult mice and served as adult controls to study the histological structure of adult splecn.

\section{Group II :}

It included five senile mice and served as senile controls to study the age related changes in the spleen.

\section{Group III :}

It included 15 adult mice of which ten mice received 1000 IU of interferon alpha subcutaneously. The dose was given three times a week for three months. Five mice received equivalent sterile water, injected subcutaneously for the same duration and served as controls.

\section{Group IV :}

It included 15 senile mice of which ten mice received $1200 \mathrm{IU}$ of interferon alpha subcutaneously. The dose was given three times a week for three months. Five 
mice received equivalent sterile water, injected subcutaneously for the same duration and served as controls.

At the end of the experiment all experimental animals were sacrificed by intraperitoneal injection of sodium thiopental $(25 \mathrm{mg} / \mathrm{kg}$ ). The abdomen was incised and the spleens were dissected and extracted. Specimens for light microscopic studies were fixed in $10 \%$ formol saline. After fixation, tissues were dehydrated, and embedded in paraffin blocks. Sections of $5 \mu \mathrm{m}$ in thickness were cut and stained with Haematoxylin and Eosin (Hx. \& E.) and Feulgen blue stain specific for nuclear DNA. Specimens for electron microscopic studies were cut into small pieces $1 \mathrm{~mm}^{3}$ in thickness, fixed in $2.5 \%$ glutraldehyde in phosphate buffer for 3 hours. Fixed tissues were washed in $0.1 \mathrm{M}$-phosphate buffer and post fixed in $1 \%$ osmium tetra oxide in 0.1 M-phosphate buffer. Dehydration in ascending grades of alcohol was followed by embedding in epon. Semithin sections $1 \mu \mathrm{m}$ werc cut using L.K.B. ultramicrotome and stained with toluidine blue. Ultrathin sections were cut and stained with uranyl acetate and lead citrate, examined and photographed with Philips 400 T.E.M.

\section{Image analysis :}

The DNA was analyzed at the pathology department of the National Research Center using the Leica Qwin 500 Image Analyzer. DNA ploidy analysis was performed on the Feulgen blue stained sections using the DNA cytometry soft ware. Selection of nuclear boundaries was performed automatically by the image analysis system. Only intact nuclei were measured, overlapping nuclei and nuclear fragments were manually eliminated from measurements. The optical density of the selected nuclei was measured and automatically converted by the system into DNA content. About $100-150$ nuclei were measured in serial sections on magnification ( $x 400$ ). The results were displayed as a frequency histogram on the moniter by plotting DNA content versus the number of nuclei. Based on the peaks produced by the histograms, the percentage of cells at each phase of cell cycle and their DNA content were calculated automatically. The results were analyzed using student t-test to compare the mean values and $\mathrm{Z}$ test compare the percentage of the cells.

\section{RESULTS}

\section{Group I \& Controls of Group II :}

Light microscopic examination of the spleen of adult mice revealed that the spleen exhibited prominent discrete white pulps suspended throughout the red pulp. 
Distinct demarcation was evident between the white and red pulps. The white pulp of the spleen existed in three discrete zones namely the periarteriolar lymphatic sheath (PALS), the lymphatic follicles and the marginal zone. The PALS consisted of closely packed small lymphocytes surrounding the arterioles in a rather regular pattern. The lymphatic follicles were rounded or oval aggregates of small lymphocytes. The lymphocytes manifested dense rounded nuclei and relatively small amount of cytoplasm. Both the (PALS) and the lymphatic follicles were surrounded by a marginal zone which appeared as a pale thin rim of less densely packed small lymphocytes with few interposed large lymphocyles (Fig. 1). The red pulp appeared as irregular cords of red blood cells mingled with few lymphocytes. The cords were separated by venous sinuses (Fig. 2).

Ultrastructural examination clarified that small lymphocytes were predominant in the PALS and the lymphatic follicles. Small lymphocytes were characterized by high nuclear cytoplasmic ratio. The nuclei were rounded or oval in shape with prominent nucleolus and moderately condensed chromatin which appeared as coarse clumps. The cytoplasm was sparse and contained very few mitochondria and comparatively large number of poly-ribosomes (Fig. 3). Large lymphocytes were noticed mainly in the marginal zone. They had indented nuclei with peripherally condensed chromatin and rounded nucleolus. The cytoplasm was relatively abundant and contained numerous rounded mitochondria, few cisterns of rough endoplasmic reticulum. Golgi complex and numerous polyribosomes distributed throughout the cytoplasm (Fig. 4).

\section{DNA Analysis of Group I \& Controls of Group III : (Tables 1, 2)}

DNA analysis of Feulgen blue stained sections of the spleen of adult mice. revealed that the majority of lymphocytes $(75.22 \%)$ were at $\mathrm{G}_{1}$ phase (presynthesis phase) of the cell cycle. The mean value of DNA was $1.94 \pm 0.26$. The percentage of lymphocytes at $\mathrm{S}$ phase (synthesis phase) of cvcle was $16.51 \%$ showing a medium proliferative index. Their mean DNA valuc was $2,85 \pm 0.29$. On the other hand few lymphocytes $(6.42 \%)$ were at Go phase (arrested phase) with a mean value of DNA $1.43 \pm 0.5$. Furthermore very few lymphocytes $(0.92 \%)$ were noticed at $G_{2}$ phase (post duplication phase) with a mean value of DNA $3,63 \pm 0$. Other lymphocytes $(0.92 \%)$ were at the aneuoploid phase with a mean value of DNA $4.515 \pm 0$. 


\section{Group II \& Controls of Group IV :}

Light microscopic examination of the spleen of senile mice showed marked regression of the white pulps throughout the prominent red pulps. The loss of lymphoid cells was apparent in both white and red pulps. Moreover, the distinct demarcation between the zones of white pulp was ill defined (Figs. 5, $6 \&$ 7). The PALS consisted of sparse lymphocytes that surrounded the arterioles in an irregular pattern. The arteriolar wall exhibited multiplc vacuolation involving the entire circumference, irregular endothelial lining and marked thickening of the muscle layer (Fig. 6). The lymphatic follicles were either shrunken or irregular in shape and exhibited marked depletion of lymphocyles. Marginal zones no longer existed as a discrcte compartment that could be distinguished from the red pulp and it appeared almost devoid of lymphocytes (Figs. 6, 7). The red pulp contained numerous extensive red blood cells, located within dilated sinuses. Meanwhile, the red pulp showed depletion of lymphocytic cells (Fig. 7).

Ultrastructural examination clarified that lymphocytes manifested various forms of degencration. Small lymphocytes though exhibited rounded nuclei with peripherally condensed chromatin, yet their cytoplasm was degencrated and ill defined. The plasmalemma was disrupted and the lymphocytes lacked the distinct cellular boundaries (Fig. 8). On the other hand, large lymphocytes manifested marked degencrative changes mainly in the cytoplasm and to a lesser extent in the nuclei. In the majority of the lymphocytes the cytoplasm presented multiple vacuolar degeneration, irregular in shape and variable in size (Fig. 9). The cytoplasmic organelles were ill defined apart from few scattered lysosomes (Fig. 10). Other lymphocytes showed in addition to the cytoplasmic degcneration, osmiophillic, pyknotic nuclei, reduced in size and with totally condensed chromatin (Figs. 10, 11). Moreover, the degenerated lymphocytes showed large cytoplasmic blebs or vcsicles protruding from the cell surface and enclosed by a plastnic membrane (Fig. 11).

\section{DNA analysis of Group II \& controls of Group IV : (Tables 1, 2)}

DNA analysis of the Feulgen bluc stained scctions of the senile mice revealed that the majority of lymphocytes $(66.34 \%)$ werc at $G_{1}$ phase showing non significant variation than adult mice $(\mathrm{P}>0.05)$. Similarly the mean value of DNA was 1.97 \pm 0.280 manifesting non significant variation than adult mice $(P>0.05$ ). The percentage of cells at $S$ phase was $18.26 \%$ showing a medium proliferative index and non significant variation than adult mice $(P>0.05)$. The mean value of DNA was $2.807 \pm 0.230$ showing again non signilicant variation than adult mice $(P>0.05)$. 
On the other hand the percentage of cells at $\mathrm{G}_{0}$ phase $(15.38 \%)$ was significantly increased $(P<0.05)$ and the mean DNA value $(1.302 \pm 0.191)$ was significantly reduced $(P<0.01)$. No lymphocytes could be detected at $G_{2}$ phase nor at the aneuoploid phase of cell cycle.

\section{Group II :}

Light microscopic examination of the splcen of adult mice which received interferon revealed that the spleen exhibited impressive. prominent white pulps even encroaching on the regressed red pulp. The distinct zones of the white pulp were amalgamated together forming a confluent mass of lymphocytes (Fig. 12). The degree of condensation of lymphocytes was variable, some areas showed highly condensed and closely packed lymphocytes, while other areas manifested loosely packed lymphocytes (Fig. 13). Most of the lymphocytes had large dark basophilic nuclei surrounded by a narrow rim of cytoplasm (Fig. 12). The red pulp contained few scattered red blood cells and obliterated sinuses (Figs. 13, 14). The characteristic finding was the presence of clusters of lymphocytes with dark basophilic nuclei and narrow rim of cytoplasm, invading the red pulp (Fig. 13). Numerous megakaryocytes were noticed infiltrating the white pulp. The megakaryocytes were large giant cells which exhibited irregular multilobed nuclei and extensive cytoplasm (Figs. 13, 14).

Ultrastructural examination, clarified signs of activation, and proliferation in the majority of the lymphocytes. The nuclei exhibited either enlarged. dispersed and homogenous chromatin (Fig. 15) or manifested loss of nuclear membrane, nucleolus and in such cases the chromatin, appeared as multiple dense blocks that were arranged approximately on either sides of the cell (Fig. 16). The cytoplasm had striking extensive proliferation of the rough endoplasmic reticulum which occupied the entire of the cytoplasm. The rough endoplasmic reticulum was concentrically arranged and consisted of regular cisterns almost of uniform diameter apart from few slightly dilated cisterns (Fig. 17). Other lymphocytes manifested partially euchromatic nuclei their cytoplasm contained few dilatcd cisterns of rough endoplasmic reticulum, scattered mitochondria and numerous free ribosomes (Fig. 18). Occasionally, the present study revealed that the plasmic membranes of some lymphocytes were opposed and adherent at localized sites but without specific cytological specialization in the area of contact (Fig. 19). 


\section{DNA analysis of group III : (Tables 1,2 )}

DNA analysis of Fculgen blue stained sections of spleen of adult micc which received interferons revealed prominent alterations. The majority of lymphocytes $(55.66 \%)$ were at $S$ phase showing high proliferative index and high significant increase than adult control $(\mathrm{P}<0.001)$. Moreover, the mean DNA value was $3.032 \pm$ 0.274 manifesting also high significant increase than the adult control $(P<0.01)$. The percentage of lymphocytes at $G_{2}$ phase $(23.59 \%)$ was significantly increased than adult control $(P<0.001)$ and their mean DNA value was $3.86 \pm 0.198$. The lymphocytes at $\mathrm{G}_{1}$ phase were significantly reduced $(16.04 \% \mathrm{P}<0.001)$. However, the mean DNA value was $2.152 \pm 0.22$ showing significant increase than adult control ( $\mathrm{P}<0.05$ ). Aneuoploid phase cells were significantly increased to $4.72 \%$ ( $\mathrm{P}<$ 0.01 ), their mean DNA value $5.408 \pm 0.682$. On the other hand, lymphocytes at $G_{0}$ could not be detected and showed high significant decrease $(P<0.01)$.

\section{Group IV :}

Light microscopic examination of the spleen of senile mice which received interferons clarified distorted splenic architecture. Multiple areas of depletion were encountered in the white pulp and numerous extensive vacuolation was noticed in the red pulp. The lymphocytes were diffuscly scattered without discrimination into zones (Figs. 20, 21). Inspite of the encountered depletion, the existing lymphocytes had large prominent basophilic nuclei surrounded by a rim of cytoplasm (Fig. 20). Megakaryocytes were infiltrating both white and red pulps (Figs. 20, 21). The red pulp consisted only of few red blood cells irregularly arranged between numerous irregular vacuoles (Fig. 21).

Ultrastructural studies revealed that the small lymphocytes had intact nuclei, and their cytoplasm showed numerous ribosomes. However, small lymphocytes cxhibited slight widening of the perinuclear space (Fig. 22). Regarding large lymphocytes, the nuclei had peripherally condensed chromatin. the cytoplasm contained multiple, dilated cisterns of rough endoplasmic reticulum scattered within the cytoplasm. The dilated cisterns showed partial detachment of ribosomes (Fig. 22). Other cells exhibited slight proliferation of the rough endoplasmic reticulum (Fig. 23).

\section{DNA analysis of group IV : (Tables 1,2 )}

DNA analysis of Feulgen blue stained sections of senile mice which received interferons clarified that the majority of lymphocytes $(47.53 \%)$ were at $S$ phase with a high proliferative index. The percentage of lymphocytes at $S$ phase was 
significantly higher than senile control $(\mathrm{P}<0.001)$. Moreover, the mean DNA value was $2.998 \pm 0.273$ significantly increased than senile controls $(P<0.01)$. The percentage of lymphocytes at $G_{2}$ phase (21.78\%) was significantly higher than senile controls $(P<0.001)$ and the mean DNA was $4.010 \pm 0.317$. The lymphocytes at $G_{1}$ phase showed highly significant decrease $(20.79 \% \mathrm{P}<0.001)$. However, their DNA mean value was $2.165 \pm 0.217$ showing highly significant increase than senile controls $(\mathrm{P}<0.01)$. The aneuoploid phase cells were atoul $9.90 \%$ showing significant increase $(\mathrm{P}<0.001)$ than senile controls. Their mean DNA value was $5.681 \pm 1.707$. The percentage of lymphocytes at $\mathrm{G}_{0}$ phase manitested highly significant decrease $(\mathrm{P}<0.001)$. 
Table 1 : Percentage of Lymphocytes in Different Phases of Cell Cycle :

\begin{tabular}{|c|c|c|c|}
\hline & $\begin{array}{l}\text { Percentage of cells } \\
\text { In different phases } \\
\text { of cell cycle }\end{array}$ & Adult Spleen & Senile Spleen \\
\hline Adult Spleen & $\begin{array}{c}\mathrm{G}_{0}: 6.42 \% \\
\mathrm{G}_{1}: 75.22 \% \\
\mathrm{~S}: 16.51 \% \\
\mathrm{G}_{2}: 0.92 \% \\
\text { Ancuoploid } 0.92 \%\end{array}$ & & \\
\hline Senile Spleen & $\begin{array}{l}\qquad \mathrm{G}_{0}: 15.38 \% \\
\mathrm{G}_{1}: 66.34 \% \\
\mathrm{~S}: 18.26 \% \\
\mathrm{G}_{2}: \\
\text { Aneuoploid : }\end{array}$ & $\begin{array}{l}Z: 2.06-P<0.05 \mathrm{~S} \\
Z: 1.43-P>0.05 \text { N.S } \\
Z: 0.33-P>0.05 \text { N.S } \\
Z:-0.96-P>0.05 \text { N.S } \\
Z:-0.96-P>0.05 \text { N.S }\end{array}$ & \\
\hline $\begin{array}{l}\text { Adult spleen } \\
\text { following } \\
\text { interferon }\end{array}$ & $\begin{array}{c}\mathrm{G}_{0}: \\
\mathrm{G}_{1}: 16.04 \% \\
\mathrm{~S}: 55.66 \% \\
\mathrm{G}_{2}: 23.59 \% \\
\text { Aneuoploid } 4.72 \%\end{array}$ & $\begin{array}{l}Z: 2.63-P<0.01 \mathrm{HS} \\
Z: 857-\mathrm{P}<0.001 \text { H.S } \\
Z: 5.88-\mathrm{P}<0.001 \mathrm{H} . \mathrm{S} \\
\mathrm{Z}: 4.99-\mathrm{P}<0.001 \mathrm{H} . \mathrm{S} \\
Z: 1.66-\mathrm{P}<0.01 \mathrm{H} . \mathrm{S}\end{array}$ & \\
\hline $\begin{array}{c}\text { Senile spleen } \\
\text { following } \\
\text { interferon }\end{array}$ & $\begin{array}{c}\mathrm{G}_{0}: \\
\mathrm{G}_{1}: 20.79 \% \\
\mathrm{~S}: 47.53 \% \\
\mathrm{G}_{2}: 21.78 \% \\
\text { Aneuoploid } 9.90 \%\end{array}$ & & $\begin{array}{l}Z: 4.16-P<0.001 \mathrm{H} . S \\
Z: 663-P<0.001 \mathrm{H} . \mathrm{S} \\
\mathrm{Z}:-4.52-\mathrm{P}<0.001 \mathrm{H} . \mathrm{S} \\
\mathrm{Z}:-5.11-\mathrm{P}<0.001 \mathrm{H} . \mathrm{S} \\
\mathrm{Z}:-3.34-\mathrm{P}<0.001 \mathrm{H} . \mathrm{S}\end{array}$ \\
\hline
\end{tabular}

HS : Highly Significant.

$S$ : Significant.

NS : Non-Significant. 
Table 2 : DNA Content of Lymphocytes in Different Phases of Cell Cycle:

\begin{tabular}{|c|c|c|c|}
\hline & $\begin{array}{l}\text { DNA content in } \\
\text { phases of cell cycle } \\
M \pm S D\end{array}$ & Adult Spleen & Senile Spleen \\
\hline Adult Spleen & $\begin{array}{l}\mathrm{G}_{0}: 1.43 \pm 0.5 \\
\mathrm{G}_{1}: 1.94 \pm 0.26 \\
\mathrm{~S}: 2.85 \pm 0.29 \\
\mathrm{G}_{2}: 3.63 \pm 0 \\
\text { Aneuoploid } 4.515 \pm 0\end{array}$ & & \\
\hline Senile Spleen & $\begin{array}{l}\mathrm{G}_{0}: 1.302 \pm 0.191 \\
\mathrm{G}_{1}: 1.97 \pm 0.280 \\
\mathrm{~S}: 2.807 \pm 0.230 \\
\mathrm{G}_{2}: \\
\text { Aneuoploid : }\end{array}$ & $\begin{array}{l}t:-2.54-P<0.01 \mathrm{HS} \\
\mathrm{t}: 9-\mathrm{P}>0.05 \text { N.S } \\
\mathrm{t}:-46-\mathrm{P}>0.05 \text { N.S }\end{array}$ & \\
\hline $\begin{array}{l}\text { Adult spleen } \\
\text { following } \\
\text { interferon }\end{array}$ & $\begin{array}{l}\mathrm{G}_{0}: \\
\mathrm{G}_{1}: 2.152 \pm 0.22 \\
\mathrm{~S}: 3.032 \pm 0.274 \\
\mathrm{G}_{2}: 3.86 \pm 0.198 \\
\text { Aneuoploid } 5.408 \pm 0.682\end{array}$ & $\begin{array}{l}\mathrm{t}: 3.104-\mathrm{P}<0.05 \mathrm{~S} \\
\mathrm{t}: 2.434-\mathrm{P}<0.01 \mathrm{H} . \mathrm{S}\end{array}$ & \\
\hline $\begin{array}{l}\text { Senile spleen } \\
\text { following } \\
\text { interferon }\end{array}$ & $\begin{array}{l}\mathrm{G}_{0}: \\
\mathrm{G}_{1}: 2.165 \pm 0.217 \\
\mathrm{~S}: 2.988 \pm 0.273 \\
\mathrm{G}_{2}: 4.010 \pm 0.317 \\
\text { Ancuoploid } 5.681 \pm 1.707\end{array}$ & & $\begin{array}{l}\mathrm{t}:-3.24-\mathrm{P}<0.01 \mathrm{H} . \mathrm{S} \\
\mathrm{t}:-2.90-\mathrm{P}<0.01 \text { H.S }\end{array}$ \\
\hline
\end{tabular}




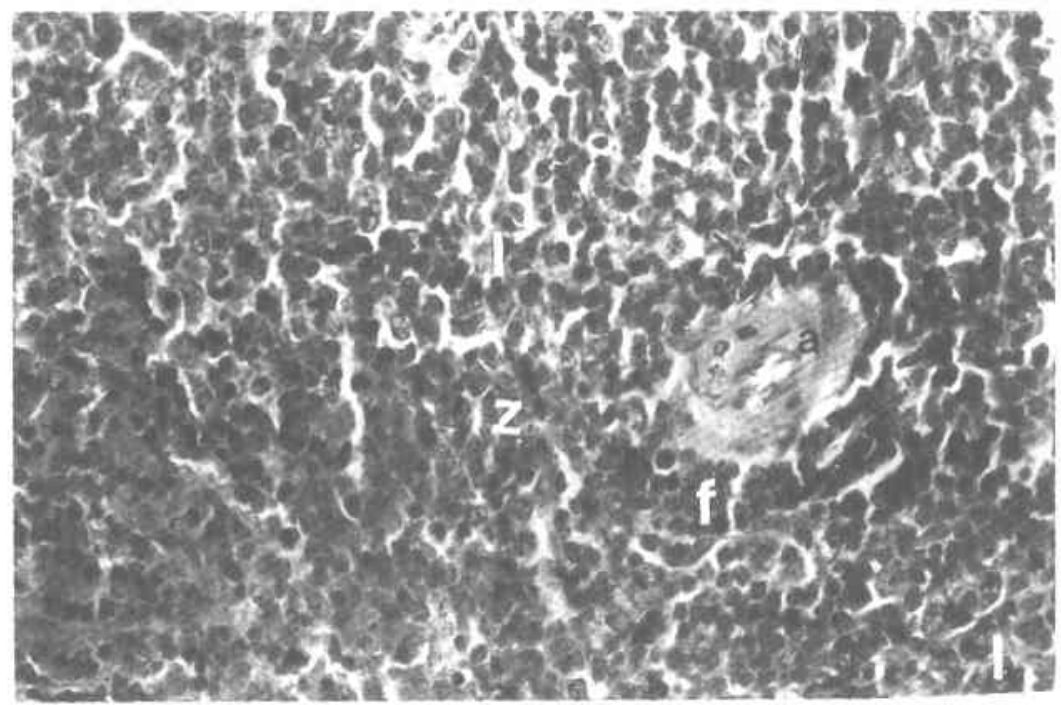

Fig. (1) : A photomicrograph of a section of the spleen of an adult mousc showing the arteriole (a) surrounded by (PAIS) ( $\uparrow$ ) lymphatic follicle (i) and narginal zone (z). Notice the large lymphocytes (1).

$\left(I I x+\& F_{2, *} ; 400\right)$

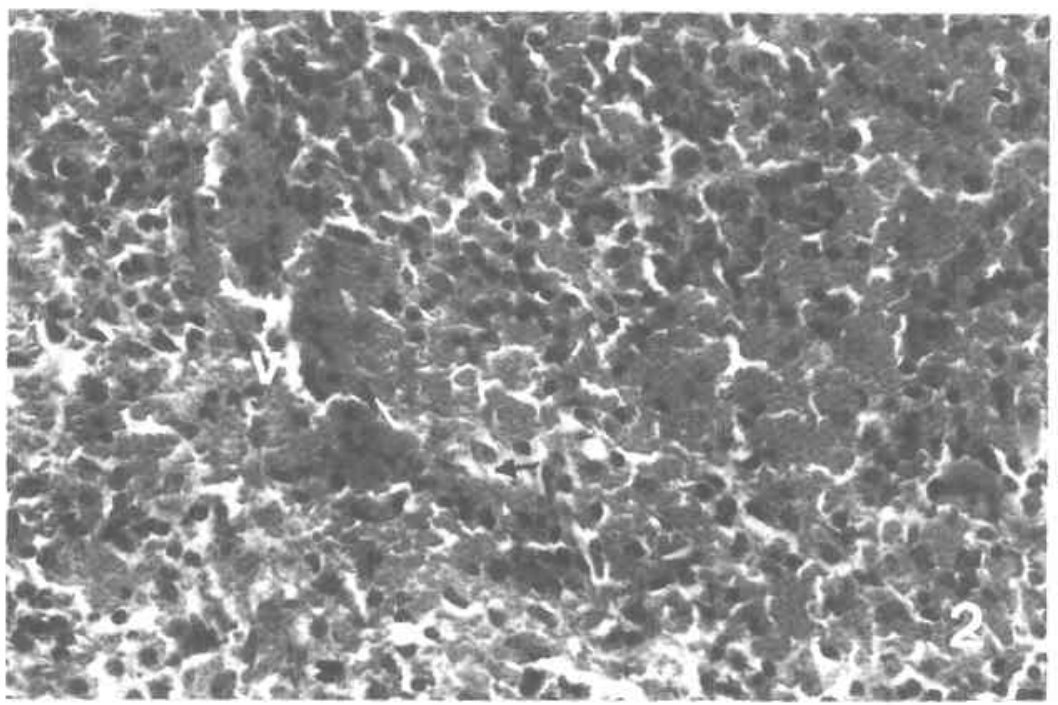

Fig. (2) : A photomicrograph of a section of the spleen of an adult mouse showing the cords of red blood cells in the red polp (T). Notice the venous sinuses (v).

(Hx, \& E.; $x 400)$ 


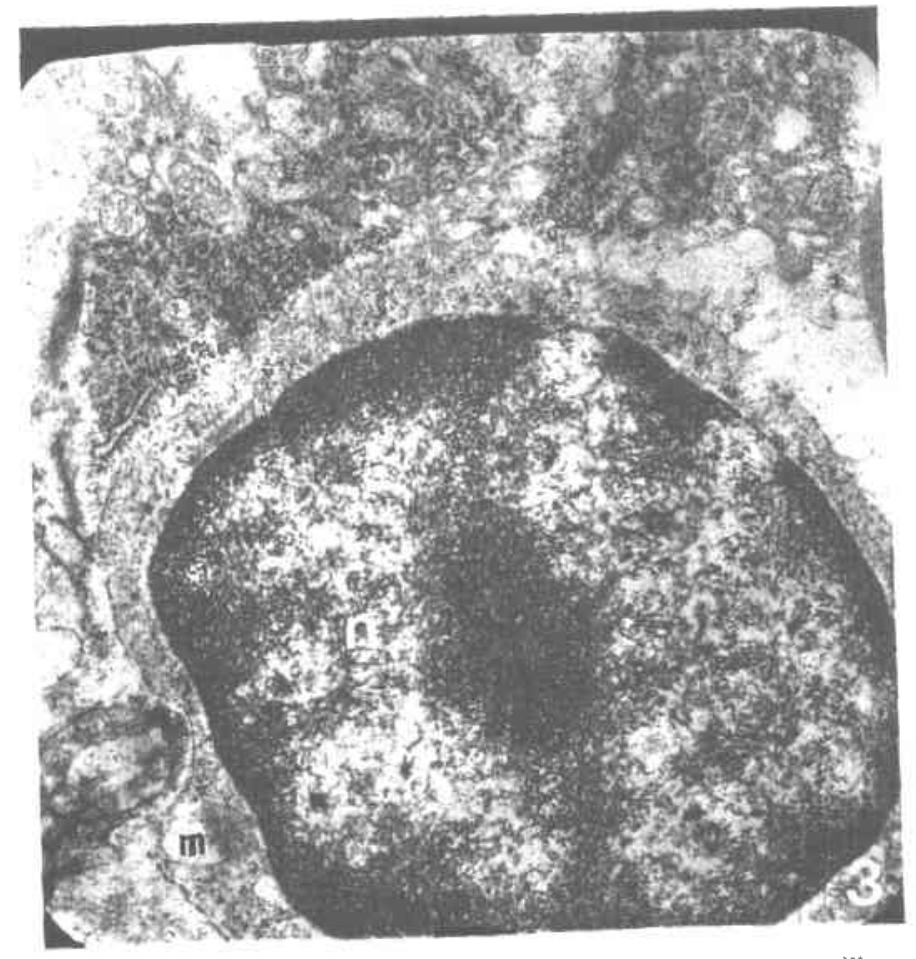

Fig. (3) : An electron micrograph of the spleen of an adult mouse illustrating a small lymphocyle with rounded nucleus $(n)$. prominent nucleolus and narrow rim of cytoplasm. Notice the mitochondria (m). (Uranyl acetate \& lead citrals: $\times 10.000$ ) 


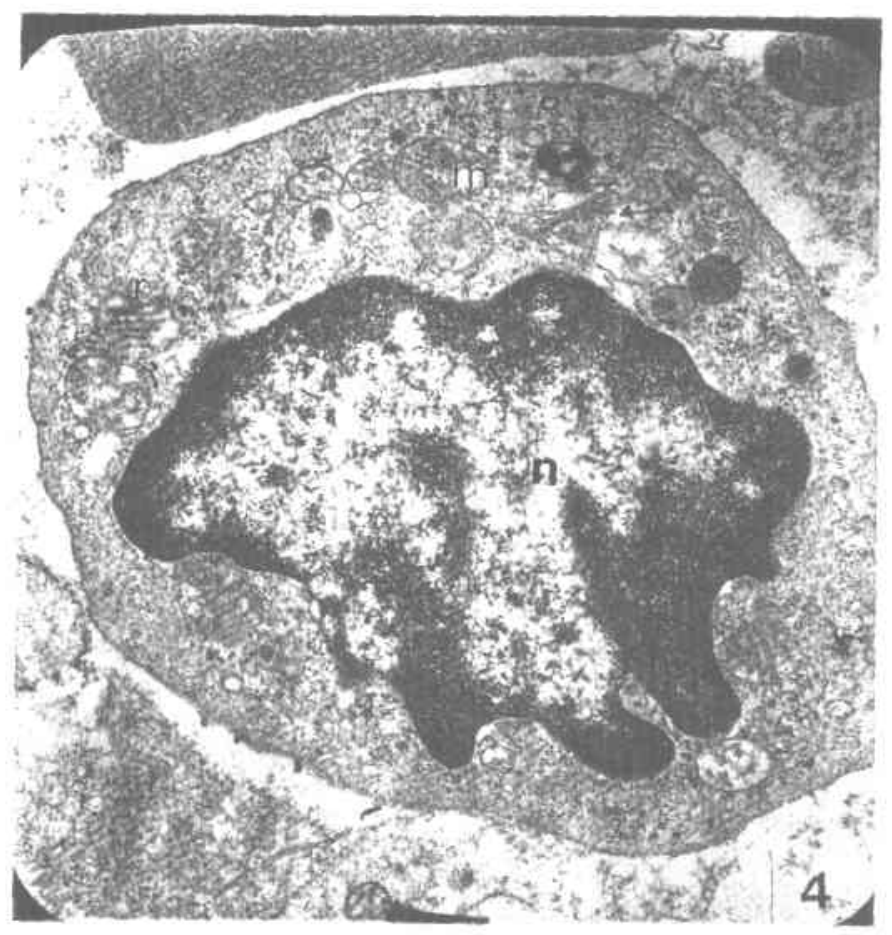

Fig. (4) : An electron micrograph of the spleen of an adult mouse showing a large lymphocyte with indented nucleus ( $n$ ). The cytoplasm has mitochondria $(\mathrm{m})$, cistems of rough endoplasmic reticulum ( $\mathrm{r}$ ), Golgi complex $(\uparrow)$ and numerous ribosonoses.

(Uranyl acetate \& lead citrate; $x$ 10.000) 


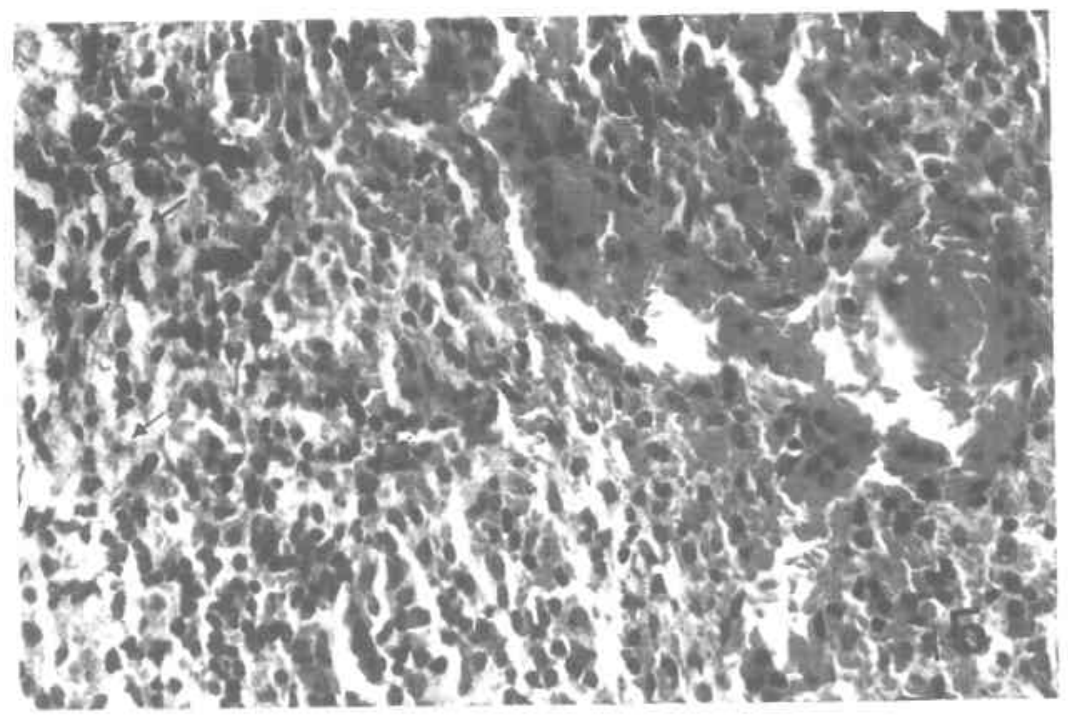

Fig. (5) : A photomicrograph of a section of the spleen of a senile mouse showing loss of lymphoid cells $(\uparrow$ ) and loss of demiarcation betwen red amd white pulps.

$($ IIx. \& $[$ :.: $\times 400)$

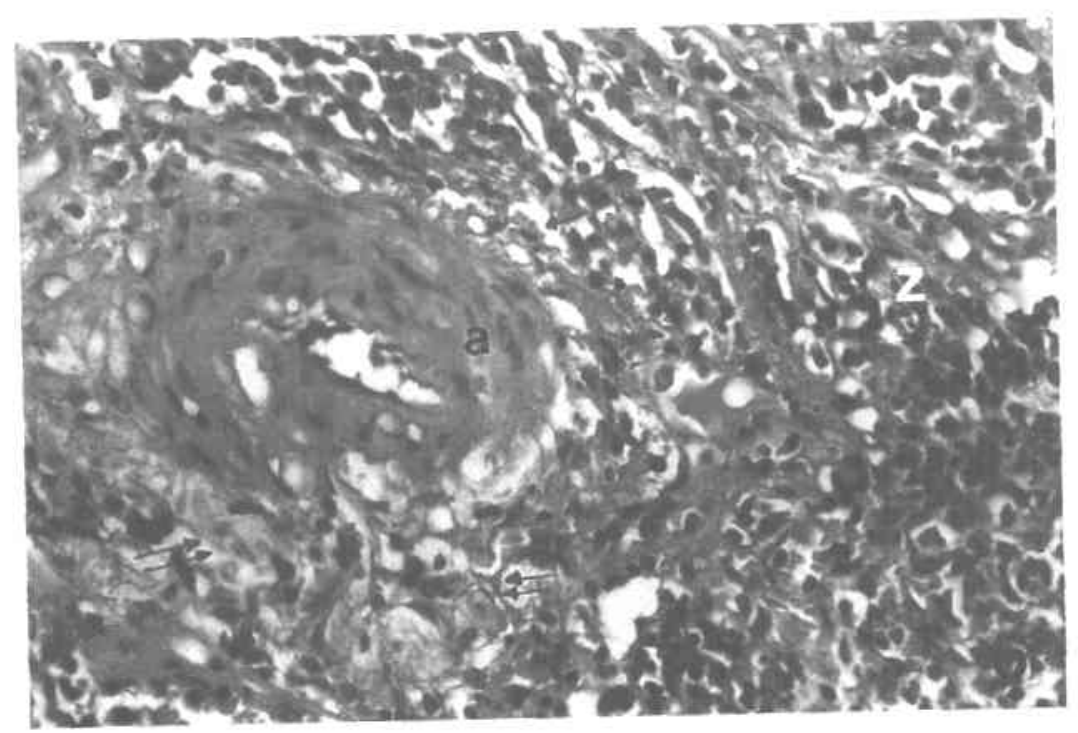

Fig. (6) : A photomicrograph of a section of the spleen of a senile mouse demonstrating the arteriole (a) with multiple vacuoles and thickened muscle layer. Notice the depletion of lymphocytes in (PAIS) ( $\uparrow$ ), lymphatic follicles $(T \uparrow)$ and the narginal zone $(\mathrm{L})$.

(Hx. \& E.; X400) 


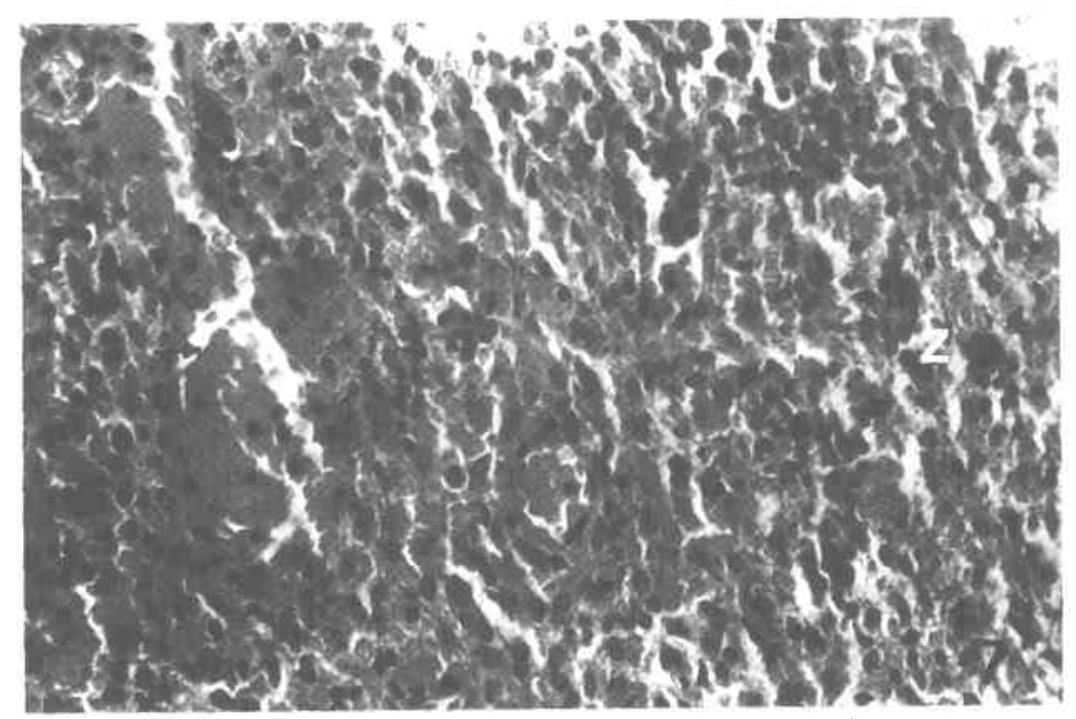

Fig. (7) : A photomicrograph of at section of the splecn of a senffle mouse revealing extensive red blood cells ( $\uparrow$ ). Notice the ill-defined marginal zone (z).

(Hx. \& E.; $\times 400)$ 


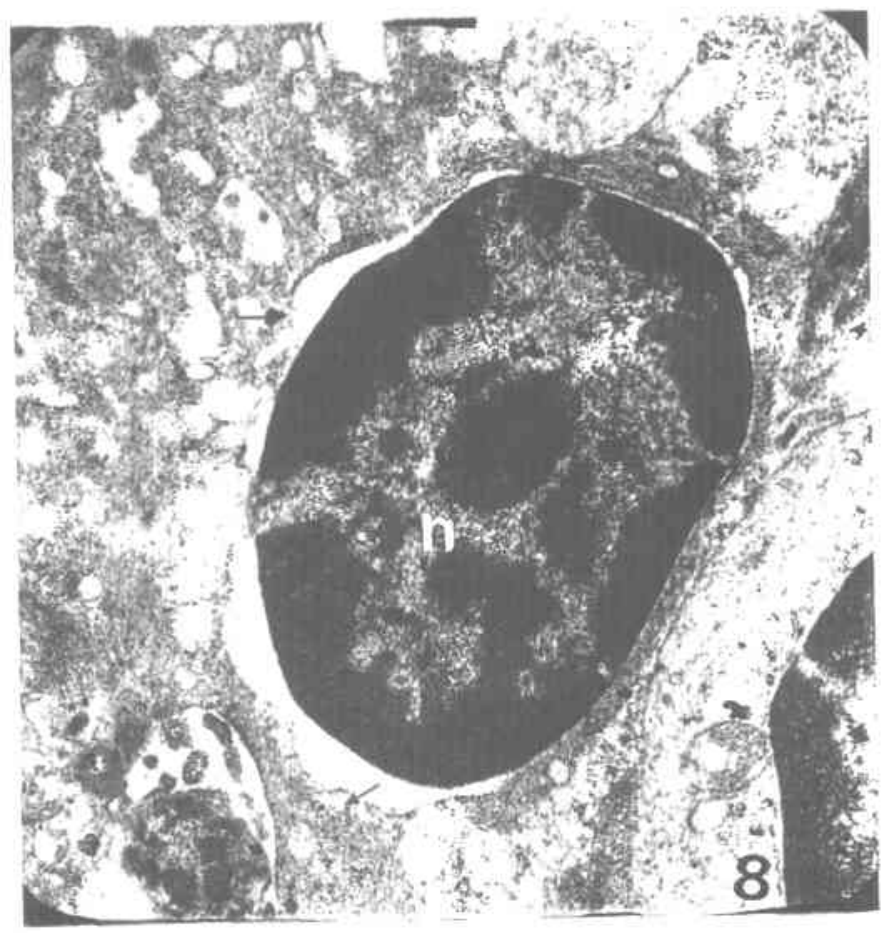

Fig. (8) : An electron micrograph of the spleen of a senile nusse shuwing a small lympho-yic wilh rounded nucleus (n) and degenerated cyloplasm. Notice the disrupted plasmalemma ( () .

(Uranyl acetatc \& lead citrate: $x$ 10.000) 


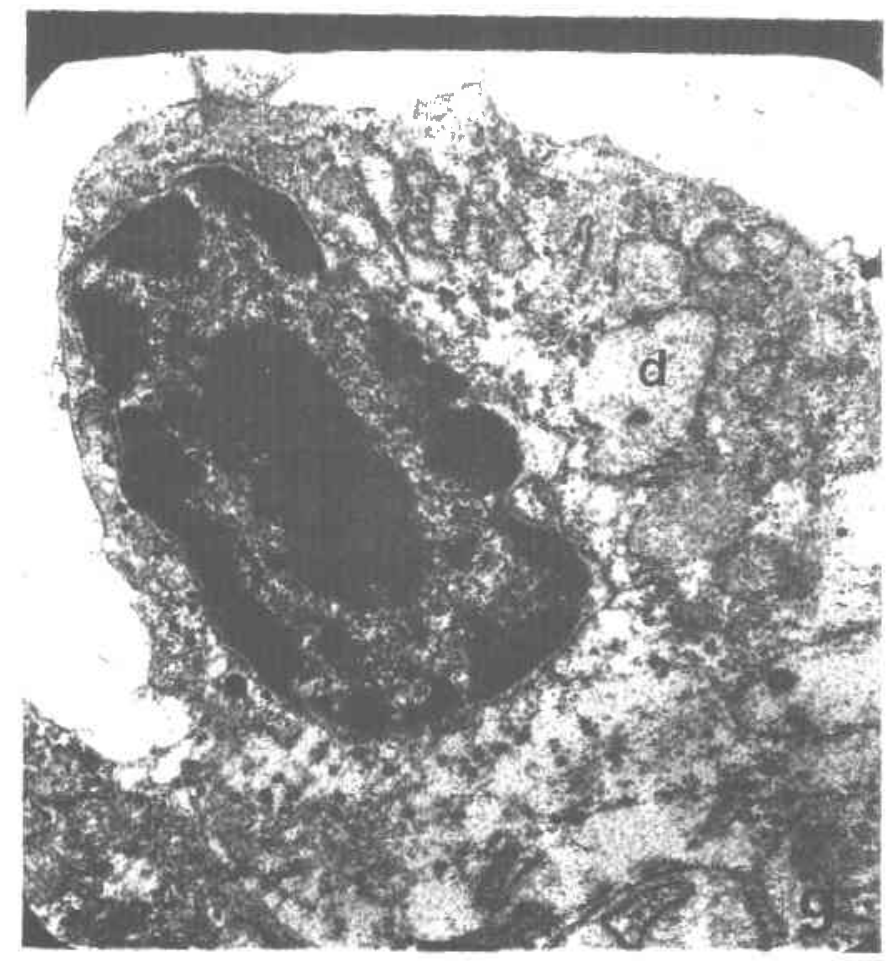

Fing. (9) : An electron micrograph of the spleen of a senile mouse showing the cytoplasm of a large lymphocyte with multiple vacuular degeneration (d).

(Uranyl acetate \& lead citrate; $x$ 10,000) 


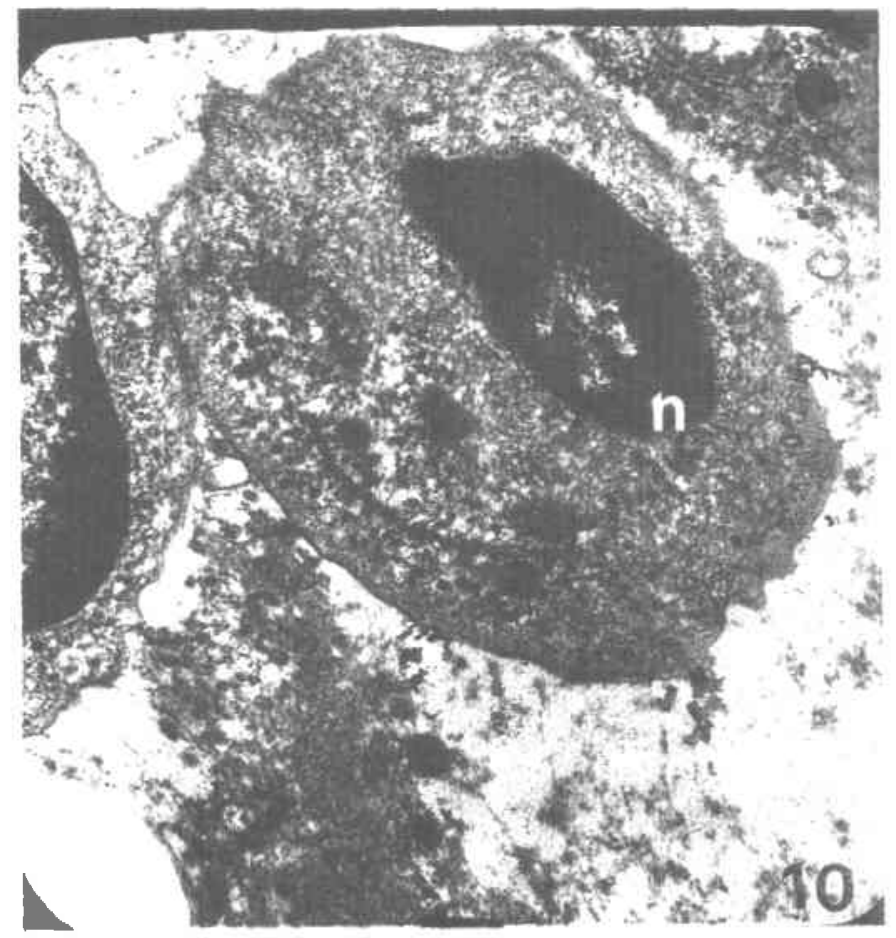

Fig. (10) : An electron micrugraph of the spleen of a senile mouse showing a lymphocyte with pyknotic nucleus $(\mathrm{n})$. The cytoplasm teveales scattered lysosomes $(\uparrow)$.

(Uranyl acetate \& lead citrate; $x$ 10.000) 


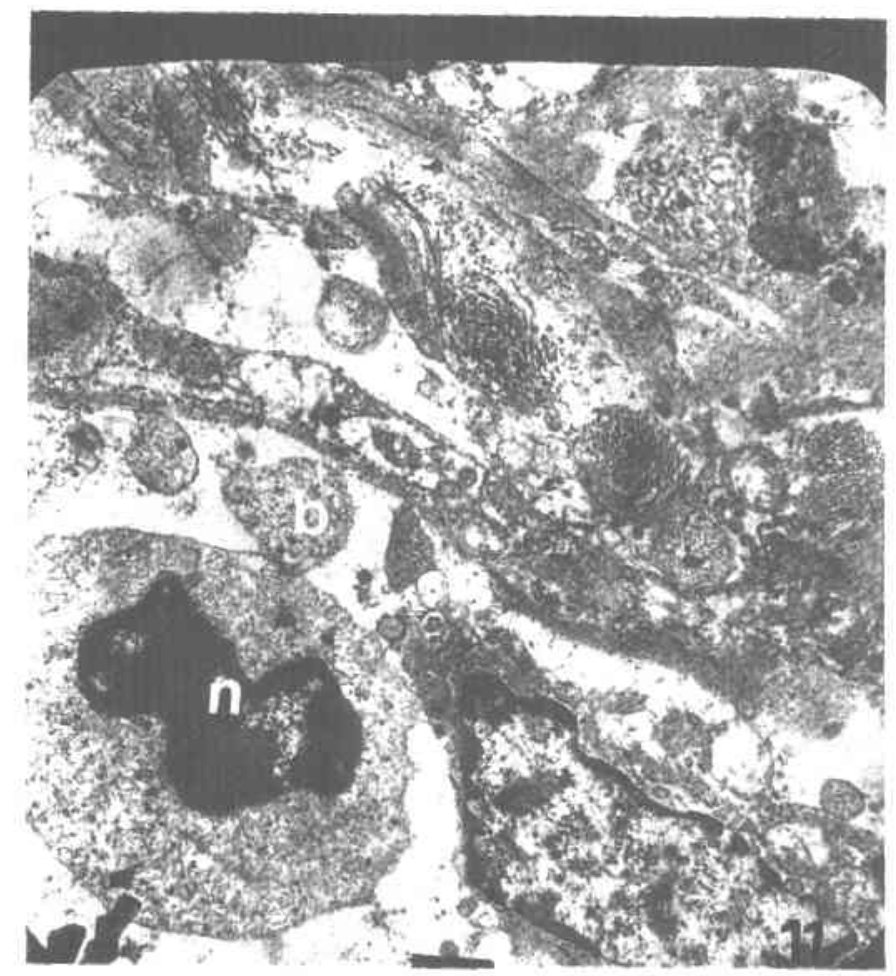

Fig. (11) : An electron micrograph of the spleen of a senile mouse denonstrating lymphocyle with pyknotic nucleos (n) and large cytoplasmic bleb (b).

(Uranyl acetate \& lead citrate; $x$ 6000) 


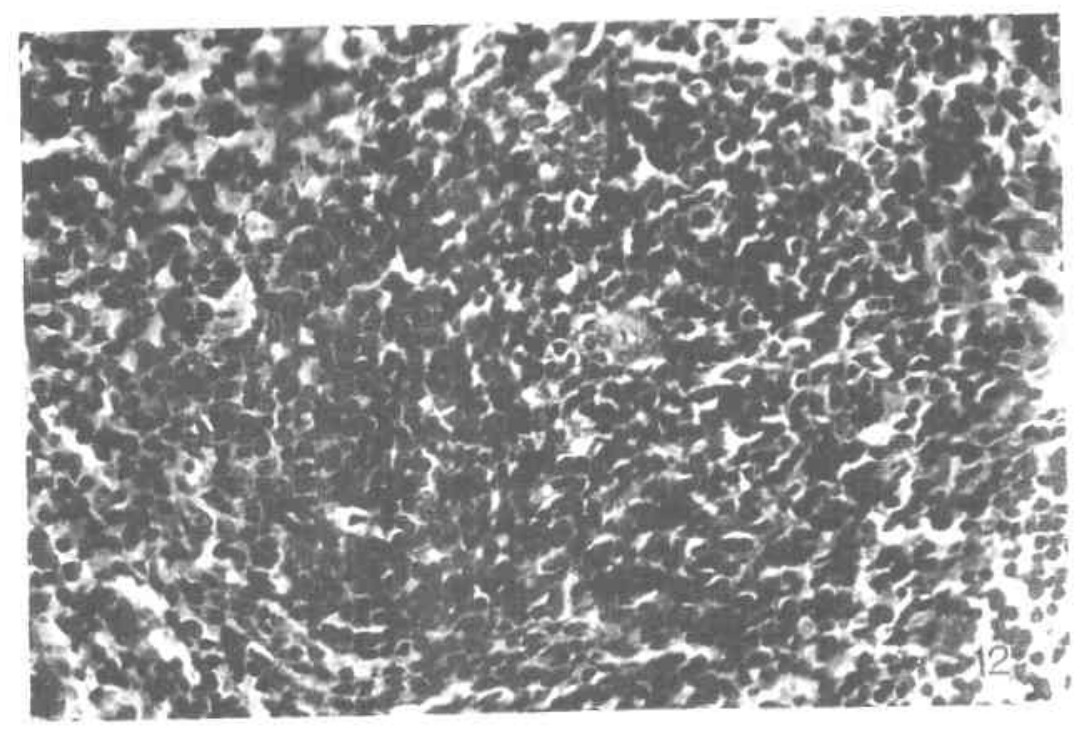

Fig. (12) : A photomicrograph of section of the spleen of an adult mouse which received interferon. Vutice the prominen white pulp and loss of themarcation between the zontes.

$(H x, \& 6 x+400)$

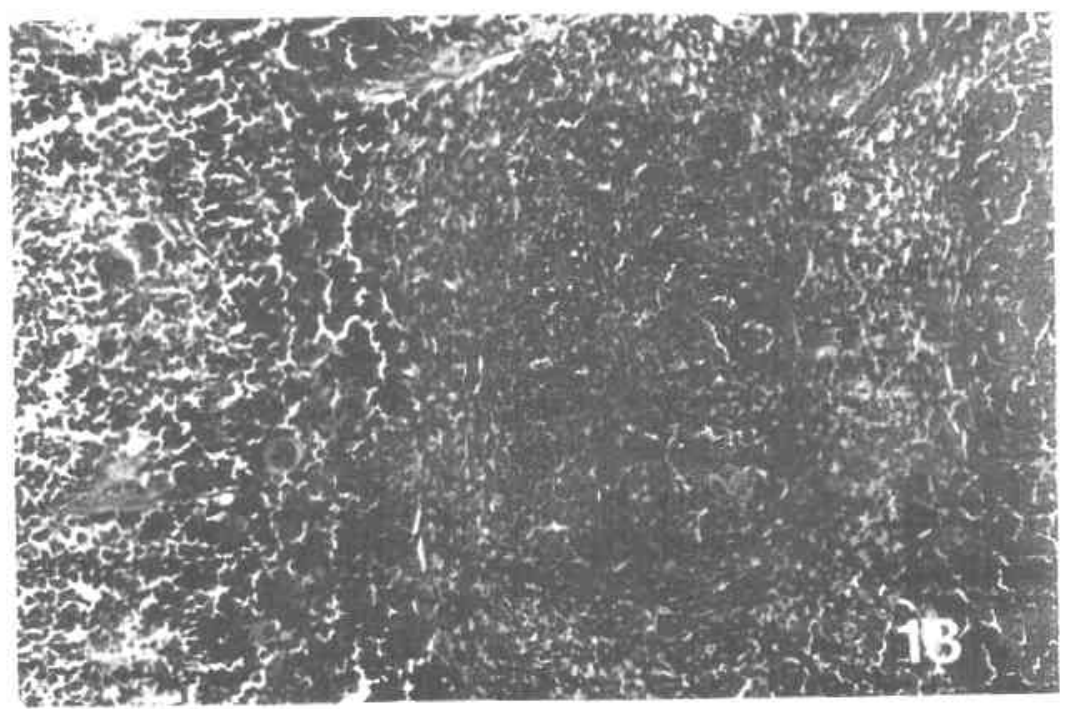

Fig. (13) : A photomicrograpl of a section of the spleen of an adult mousc which received interferon showing the variation in the condensation of lymphocytes. Notice the regressed red pulp (

$(\mathrm{Hx}, \&[\mathrm{~F}: \mathrm{x}, 2 \times)$ 


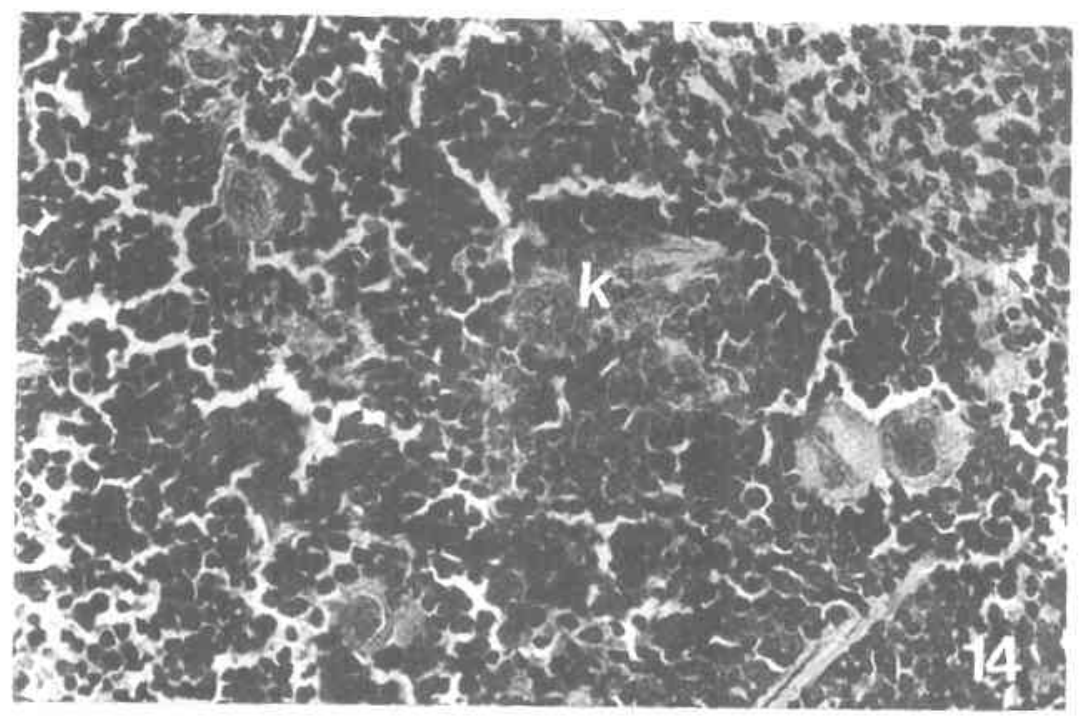

Fig. (14) : A photomicrograph of a secton of the splect of an adult mouse which reccived interferon showing megakaryocyles $(\mathrm{k})$.

$(\mathrm{Hx}, \& \mathrm{E} ; \mathrm{x} 400)$ 


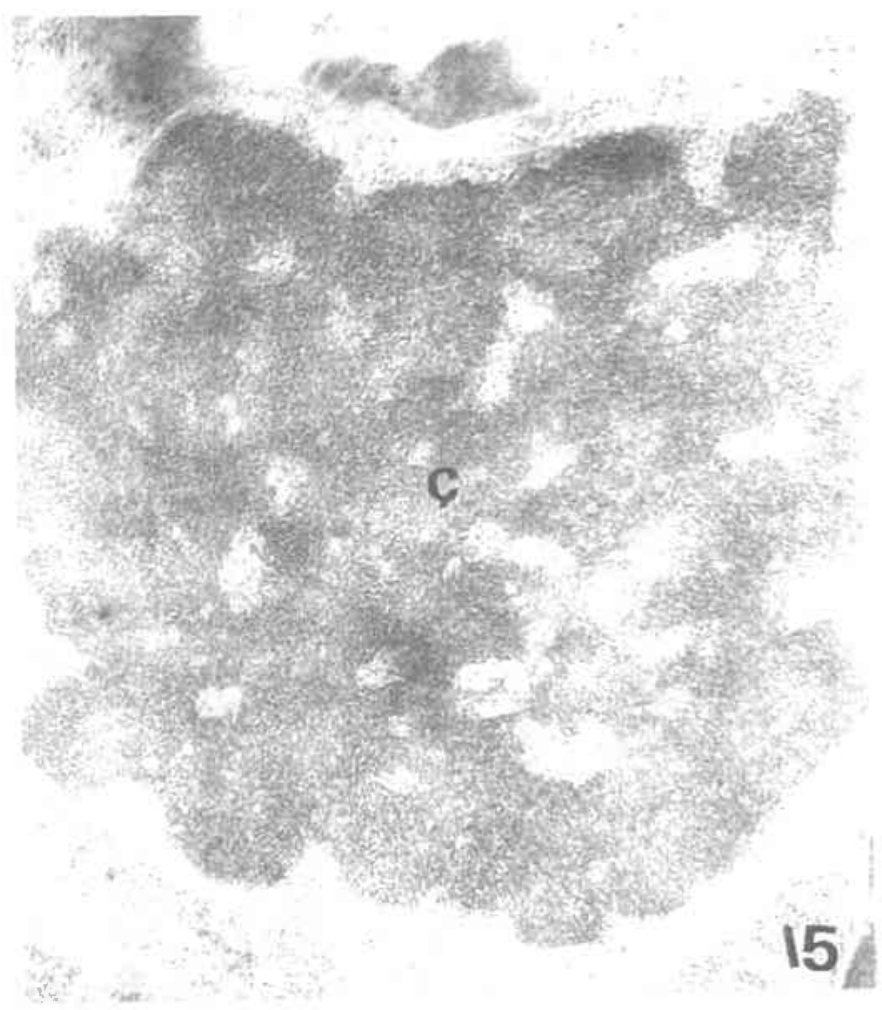

Fig. (15) : An electron micrograph of the spleen of an adult mouse which received interlerm showing an enlatged. homogeneous dispersed chromatin (c).

(Uranyl acetate \& ladd citrite; $\times 22.000$ ) 


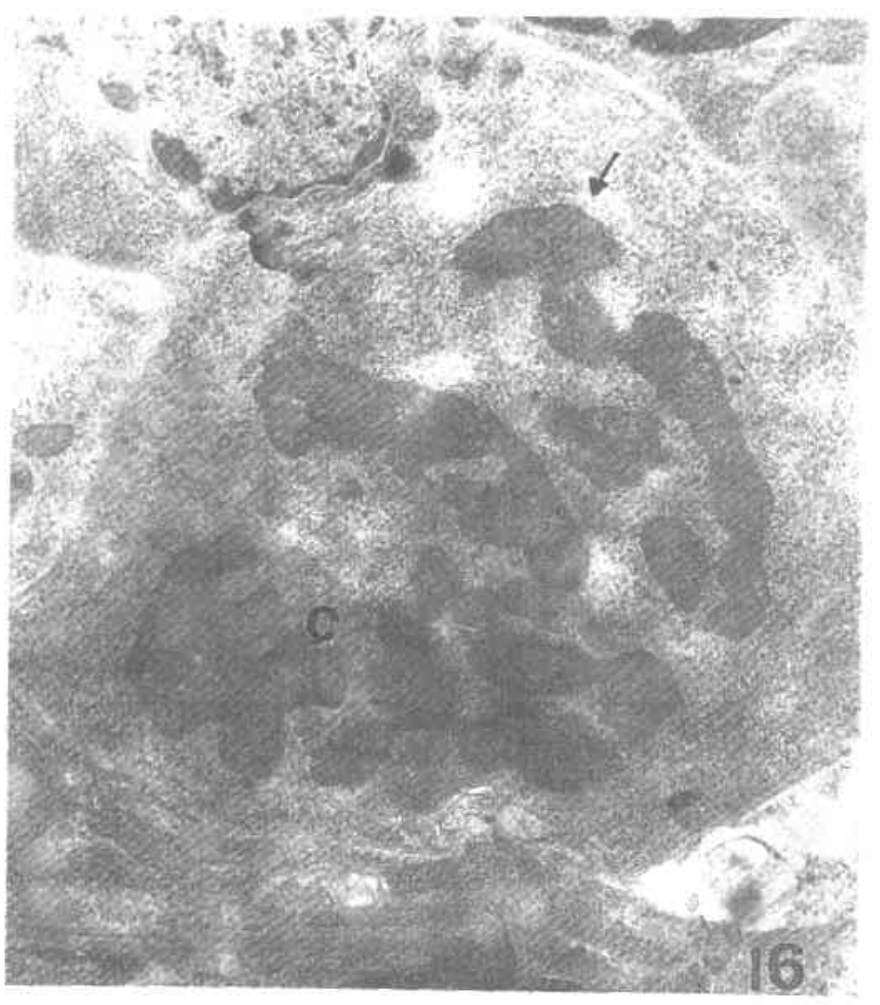

Fig. (16): An electron micrograph of the spleen of an adult mouse which received interferon showing loss of nuclear menbrane ( $\uparrow$ ). Notice the dense multiple chromatin clumps (c).

(Uranyl acetate \& lead citrate; $x$ 10.000) 


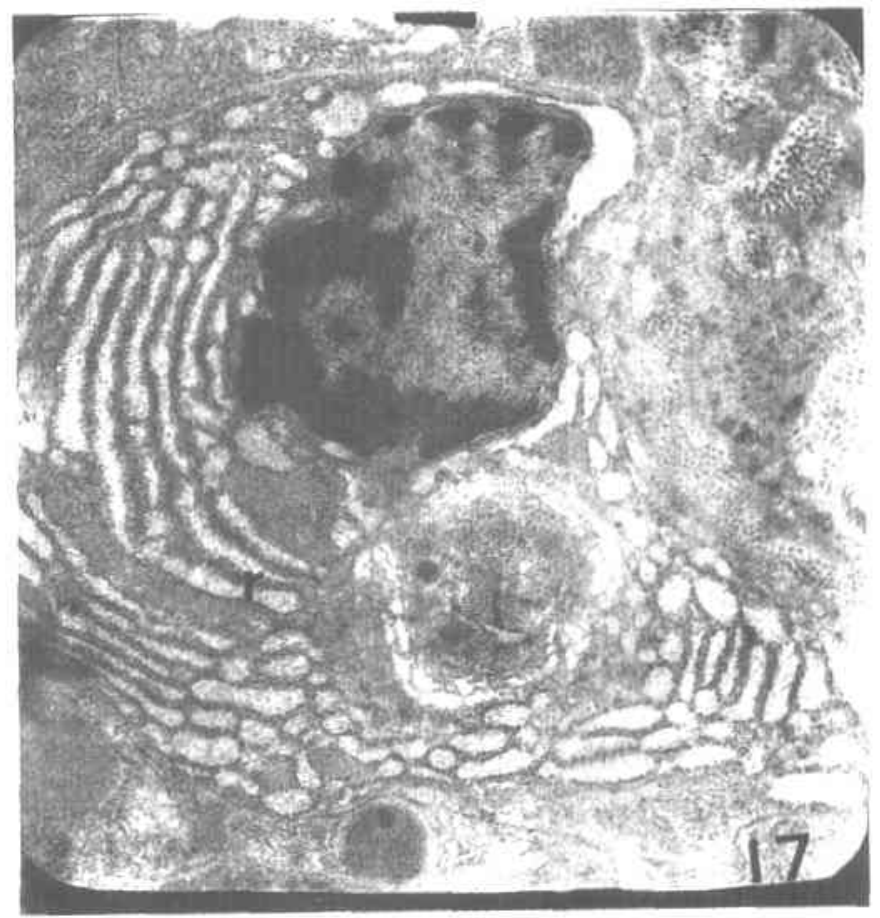

Fig. (17): An clectron mscrouraph of the splecen of an adult mouse which received interticun demonsirating marked proliferation of rough endoplasmic reticulum (r).

(Uranyl acetatc \& lead citrate: $x 3000$ ) 


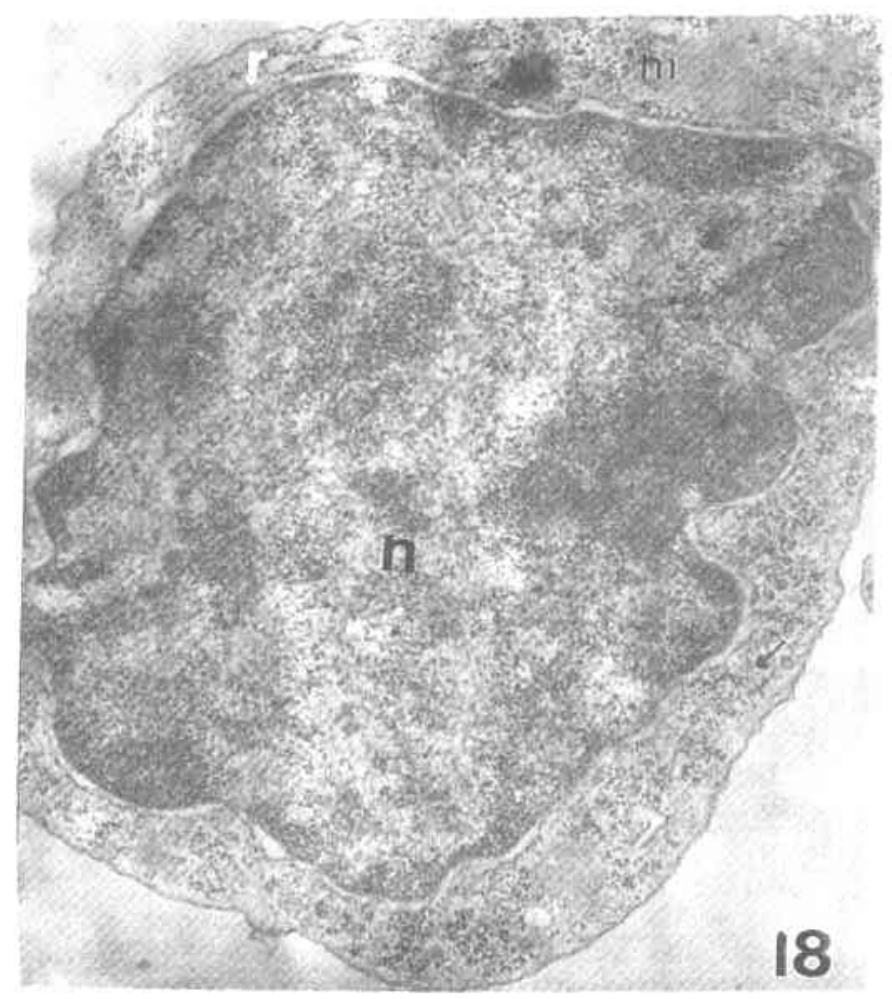

Fig. (18) : An electron micrograph of the spleen of an adult mouse which received interferon showing a lymphocyle with euchromatic nucleus (n). "The cytoplasm shows dilated eistems of rough endoplasmic reticulum ( $\mathrm{r}$ ) mitochondria $(\mathrm{m})$ and numerous polyribosomes $(\mathrm{T})$.

(Uranyl acetate \& lead citrate; $x .17,000$ ) 


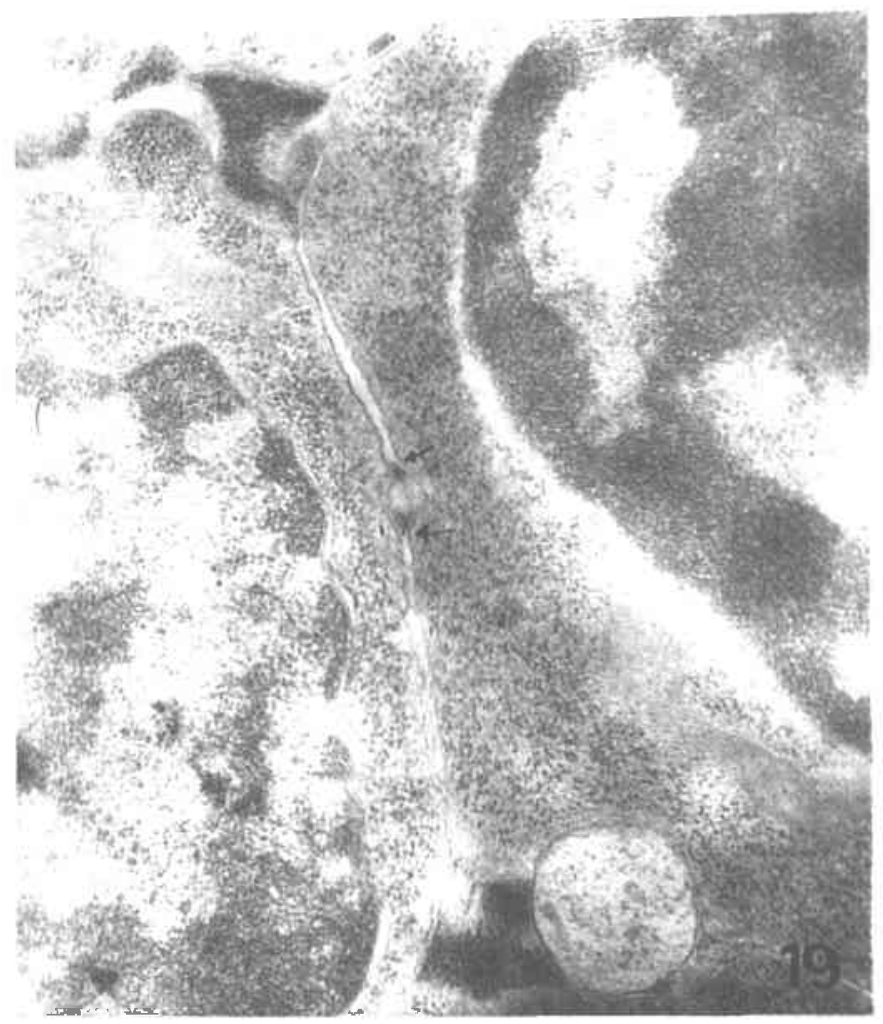

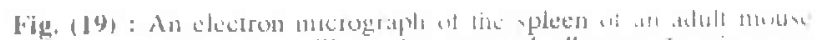
which received interferon illustrating opposed adherent plasmic membrancs at lixalized sites ( $\uparrow$ ).

(Uranyl acetatc \& kiad citrate; $x$ 22.000) 


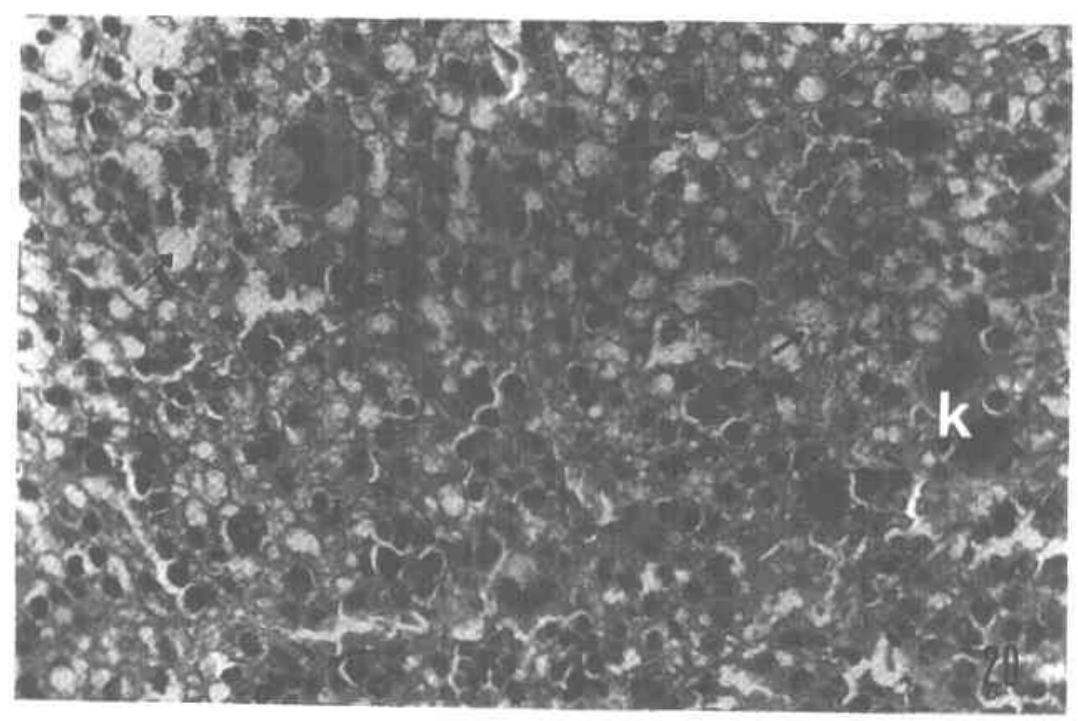

Flg. (20) : A photomicrograph of section of the spleen of a senile mouse which received interferon showing distorted splenic architecture and depletion of lymphocytes in white pulp $(\uparrow)$. Notice the megakaryocytes $(\mathrm{k})$.

(Hx. \& E,; x 400)

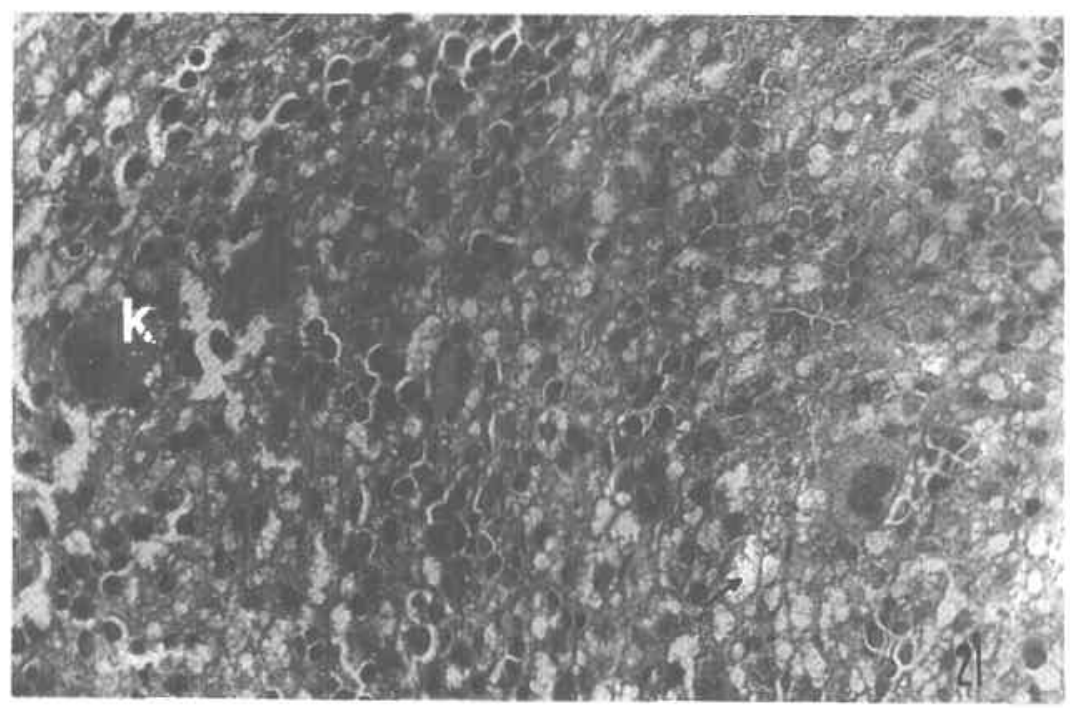

Fig. (21) : A photomicrograph of a section of the spleen of a senile mouse which received interferon demonstrating multiple vacuolation in the red pulp
$(\uparrow)$. Notice the megakaryocytes $(k)$.

(Hx. \& $\left.\mathrm{E}_{;} ; \mathrm{x} 400\right)$ 


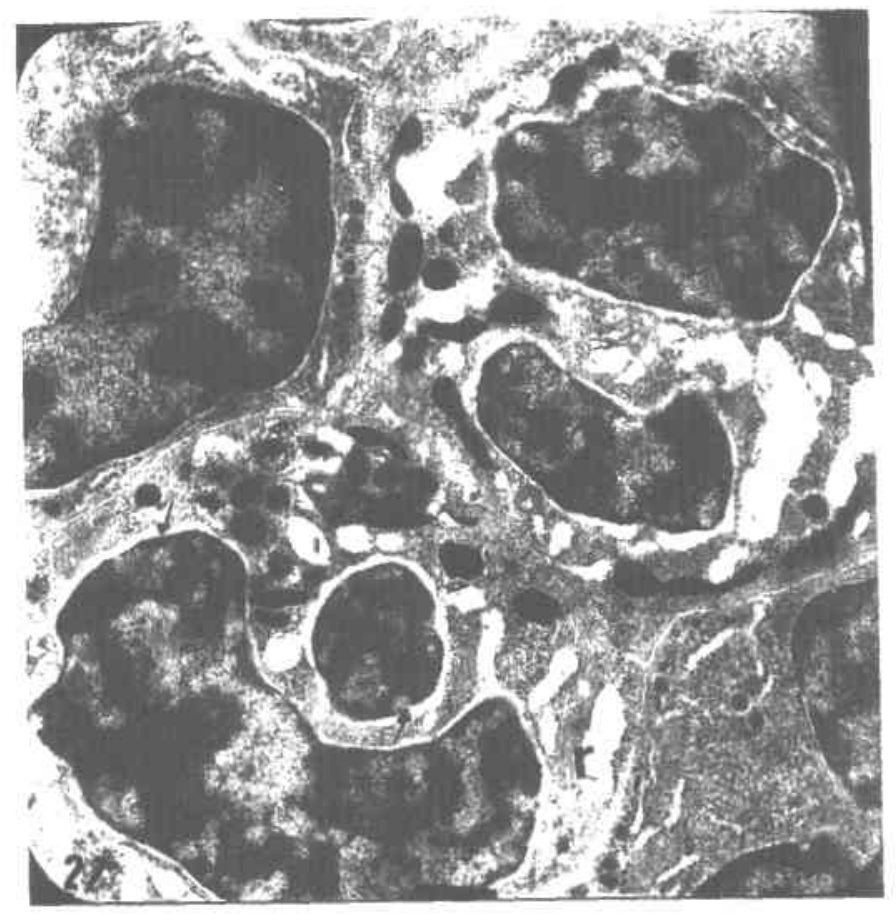

Fig. (22) : An electron micrograph of the spleen of a senile mouse which received interferon demonstrating lymphocytes with muliple dilated cistems of rough endoplasmic reticulum (r) and detached ribosomes. Notice the widening of perinuclear space $(T)$.

(Uranyl acetate \& lead citrate; $x$ 3000) 


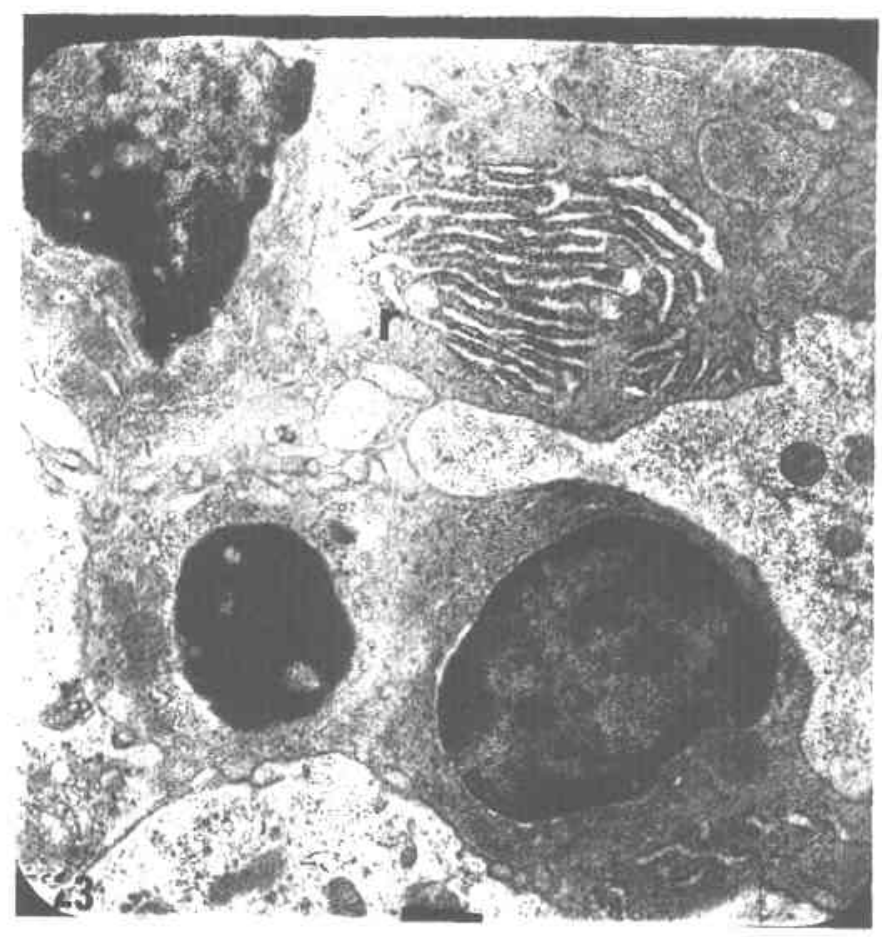

Fig. (23) : An electron micrograph of the spleen of a senile nouse which reccived interferon showing proliferation of the rough endoplasmic reticulum (r).

(Uranyl acetate \& lead citrate; $x$ 3000) 


\section{DISCUSSION}

The present study clarified that administration of interferon alpha has provoked profound alterations in the splenic architecture. It enhanced the proliferation of lymphoid tissue essentially required to allow interferon to exert its immunomodulatory effects in adults. However, aging seems to aher the response of the spleen.

Following administration of interteron. the spleen of adult mice exhibited impressive prominent white pulps. Moreover, the present work revealed that the distinct zoncs of white pulp, namely, the PALS, the lymphatic follicles and the marginal zone were amalgamated together forming a confluent mass of condensed lymphocytes. However, the degree of condensation of lymphocytes was variable. The extensive amalgamation and accumulation of lymphocytes could be attributed to the ability of interferon to induce tralfic of lymphocytes within the spleen. Moreover, interferon could enhance pooling of lymphocytes from bone marrow and lacilitate their subsequent accumulation in the other compartments as the spleen or lymph nodes (Salazar et al., 1996). The characteristic finding of the present study was the apparent regression of the red pulp as clusters of small lymphocytes entirely encroached on the red pulp. The lymphocytes had dark basophilic nuclei. narrow rim of cytoplasm and were more or less similar to those seen in the (PALS) and lymphatic follicles. Interterons could relocalize cells from white pulp to red pulp region or enhance the traffic along the splenic red pulp. Such migratory pattern might localize lymphocytes in a special order to reccive additional activation signals or might play a role in lymphocytic proliferation (Salazar et al., 1996). Interferons have been showing to up regulate adhesion molecules important for different phases of lymphocyle migration from the blood via endothelial venules or through the lymphoid organs (Pabst \& Westermann, 1994).

The present work further demonstrated that the majority of lymphocytes exhibited signs of activation and proliferation. Ultrastructural examination clarified that the nuclei had cilher colarged dispersed homogenus chromatin or manilested loss of nuclear nembrane, nucleolus and the chromatin was aranged as dense blocks on either sides of the cell. The morphological appearance of chromatin encountered represent the prophase stage of mitosis (Junqueira \& Carneiro, 2003). In addition, the cytoplasm exhihiled striking proliferation of the rough endoplasmic reticulum which occupied the entire of the cytoplasm. The rough endoplasmic reticulum was concentrically arranged, 131 consisted of regular cisterns of uniform caliber a part from lew dilated cisterns. The expanded uniform proliferation of the rough 
cndoplasmic reticulum is a prominent morphological sign of lymphocytic activation (Singh et al., 1998). Siructurally, these cells bear the features of plasma cclls indicating that alpha interferon could initiate a synchronized terminal differentiation of lymphocytes into plasma cells. In vitro-sludies indicated that interferon exclusively might have a proliferative enhancing effects on B cells. However, it was not clear if secondary mediators were participating in plasma blast formation (Steinger \& Van der Meide, 1993). The activated B lymphocytes might achieve a faster and more coordinated immune responses which could be a part of the mechanism that allows interferon to achieve its immune modulator effects. (Bosio et al., 2001).

Although lymphocytes could be activated by interferon therapy, recently a group of natural interferon producing cells were recognized normally in the T ceII zone of the lymph nodes and in the marginal zones of the spleen. Ultrastructurally, the natural interferon producing cells or the so called plasmacytoid dendertic cells display the ultrastructural characteristics resembling those of human plasmacytoid cells and could produce interferons after viral stimulation (Martin et al., 2002). It is postulated that interferon therapy initiates signals that arc transducted via cell to cell interactions, a possible intermediate in the signal transduction pathway is the natural interferon producing cells which possess interferon receptors on their surface. Interferon therapy might help maturation and differentiation of natural interfcron producing cells (Bosio et al., 2001). Moreover, it is hypothesized that the ability of natural interferon producing cells to respond to exogenous interferon is essential for generation of fully activated dendertic cells (Montoya et al., 2002).

The present work clarified another form of activated lymphocytes. The cells beared partially euchromatic nuclei, and their cytoplasm contained few dilated cisterns of rough endoplasmic reticulum, scattered mitochondria and numerous free ribosomes. These are probably activated T lymphocytes (Junqueira \& Carneiro, 2003). The activation of various types of $T$ lymphocytes following interferon alpha has been reported in previous experimental studies. Immunohistologic and flow cytometric analysis showed marked infiltration of activated $\mathrm{T}$ lymphocytes (CD8) in wild type tumors of mice inoculated with interferon alpha expression cells, suggesting that interferon alpha can induce cytotoxic $\mathrm{T}$ lymphocytes and elicite long lasting tumor immunity (Eguchi et al., 2003). Moreover, administration of interferon I mainly the beta subtype significantly increased the proportion of natural killer $\mathrm{T}$ lymphocyte (NKT) as well as natural killer cells (NK) in the spleen of rat (Suzuki et al., 2002).

The interferon activated lymphocyles particularly natural killer cells (NK) can produce a variety of growth factors for hematopoiesis and exert significant 
hematopoictic growth promoling effects (Murphey et al., 1992). The hematopoietic effect of natural killer cells could explain the presence of numerous megakaryocyles noticed in the present study in the red and white pulps of adult spleen following interferon administration. The present work further clarilied a peculiar phenomena as it revealed that the plasmic membranes of some lymphocytes were opposed and adherent at localized sites. Such adhesion of lymphocytes might allow ccoperation or might even assist in the movement of stimulating and differentiating factors between the adjacent lymphocytes to enhance the immune responses (Han et al., 2003).

The nitotic morphological changes noticed in the present study is a visible manifestation of cell division, but other processes play a fundamental role in the cell multiplication among these is the phase where DNA replicates during the interphase. The interphase is divided mainly into $G_{1}$ phase (presynthesis). $S$ phase (DNA synthesis) and $\mathrm{G}_{2}$ phase (DNA duplication) (Junqueira \& Carneiro, 2003). The present study demonstrated by image analysis of Feulgan blue stained sections that the majority of lymphocytes of adult splecn were at $G_{1}$ phase and $S$ phase of cell cycle with a medium proliferative index. On the other hand. few lymphocytes were at $G_{0}$ phase and to a lesser extent at $G_{2}$ phase or aneuoploid phase of cycle. Administration of interferon to adult mice induced prominent alterations in the cell cycle. Interferon significantly increased the percentage of lymphocytes at $S$ phase with a high prolifrative index. The lymphocytes at $S$ phase represented the majority of the cells. Interferon, as well, significantly increased the lymphocytes at $\mathrm{G}_{2}$ phase and aneuoploid phases. These changes were associated with simultaneous significant reduction in the percentage of lymphocyles at $\mathrm{G}_{1}$ phase. Moreover, no lymphocytes could be observed at $G_{0}$ phase of the cell cycle. These results suggest that following interteron the majority of lymphocytes were in the active phase of cell cycle and might indicate a close relationship between the proliferative immune enhancing action of interferon and the cell cycle. The enhancing effects of interferon on the lymphocytes at $S$ and $\mathrm{G}_{2}$ phases are contrary to its effects on the hepatocytes. It was reported that interferons decrease the number of hepatocytes at $S$ and $G_{2}$ phases of the cell cycle while they increase the number of liepatocytes in $G_{0}$ and $G_{1}$ phases. Interferon suppresses the proliferation of liver cell by inducing cell arrest and apoptosis mainly at the $S$ and $\mathrm{G}_{2}$ active phases of the cell cycle (Kim et al., 2000).

The present work further revealed that the DNA content of lymphocytes at S phase $\mathrm{G}_{2}$ phase and aneuoploid phase wals significantly increased. Although the lymphocytes at $G_{1}$ phase were significantly reduced in number yet their DNA content was also significantly increased. Again, these results were contrary to the reported 
effects of interferon on hepatocytes. It has been shown that interferon suppresses hepatic DNA synthesis in mice. The inhibitory effects were attributed to suppression of cyclic adenosine monophosphate and ornithine decarboxylase enzyme activities in the hepatic cells (Theocharis et al., 1997).

Regarding senile mice, the present work clariflied that aging induced eminent morpholngical changes in the spleen. The white pulp manifested marked regression with loss of the distinct demarcation of the different zones. Moreover, the present study illustrated marked depletion of lymphocytes in the white and red pulps. PALS is believed to be a $\mathrm{T}$ lymphocyte dependant zone while the marginal zones and lymphatic follicles are mainly B lymphocyte regions (Steinger \& Van der Meide, 1993). Pronounced depletion was noticed in the present study in the lymphatic follicles and the marginal zone. PALS exhibited sparce lymphocytes that surrounded arterioles in an irregular pattern. The generalized depletion of lymphocytes encountered in the present work is suggestive of depletion of both $B$ and $T$ lymphocytes. Aging is believed to be associated with reduction in $\mathrm{B}$ cell population and reduction in all subtypes of $T$ cells including $C D_{4}$ and $C D_{8}$ (Watanabe et al., 2001; Woods et al., 2003). The existing $T$ cells are less capable of promoting $B$ cell differentiation (Howel et al., 2003). However, the ability of the existing B lymphocytes to respond to antigens and to differentiale into high affinity antibody secreting cells appeared to be intact (Daiely et al., 2001).

Ultrastructural studies of the splecn of senile mice showed that the small lymphocytes had intact nuclei but the cyloplasm was degenerated. Moreover, the plasmalemma was disrupted and the lymphocytes lacked the distinct cellular boundaries. The damage of the cell membrane could be atributed to age associated relcase of free radicals. Membranes damaged by radicals usually become more rigid and exhibit decrease permeability. These changes could lead to reduced function and in fact might result in disruption of cell membrane (EI Sokkary et al., 2003).

Large lymphocyles manifested marked vacuolar cytoplasmic degeneration and ill-defined cytoplasmic organelles. Morcover, some lymphocytes exhibited in addition to cyloplasmic degeneration numerous pyknotic nuclei. Large cytoplasmic blebs enclosed by plasmic membranes were noticed protruding from the cell surface. Such cells are presenting signs of apoptosis. Enhanced apoptosis in aging lymphocytes was recently attributed to oxidative stress (Schindowski et al., 2001). Apoptotic cells alter the immune responscs and reduce the overall activity of immune competent cells. Moreover, it might be the cause of the decline in humoral immunity associated with aging (Eaton-Bassirie et al., 2000). 
Image analysis of the Feulgen blue stained sections revealed that the majority of lymphocytes were at $G_{1}$ phasc and $S$ phase of cell cycle with a medium proliferative index. Both phases did not exhibit significant variation in their percentage of cells nor in their DNA content than adult mice. On the other hand the percentage of lymphocytes at $\mathrm{G}_{0}$ phase was significantly increased simultancously with significant decrease in their DNA content. The altcrations encountered in the $G_{0}$ phase in the senile cell cycle is suggestive of increase tendency of arrest of cell division. This could be probably attributed to increase in DNA damage and mutations that occur with age, associated with reduced ability to repair the damaged DNA (Cabelof et al., 2002). Furthermore, the decrease in the DNA content could be attributed to the increase incidence of anti DNA auto antibodics which localize within B cell follicles (Eaton - Bassirie et al., 2000).

Following administration of interferon to senile mice the spleen exhibited distorted and exhausted architecture. Multiple areas of depletion were encountered in the white pulp together with multiple vacuolation in the red pulp. Numerous lymphocytes were diffusely scattered without discrimination. In spite of the encountered depletion, the existing lymphocytes did not reveal by light or electron microscopic examination evident signs of apoptosis. The lack of apparent cellular necrosis in the small and large lymphocytes in spleen of senile animals which received interferon might suggest that the depleted lymphocyles left the spleen in response to interferon administration. Il could be speculated that thesc cells were mobilized from spleen to peripheral areas and that such mobilization is a part of mechanism that might allow interferon to be eflective in senile mice (Bosio et al., 2001). The inability of lymphocyles to replenish the peripheral compartments in aged mice is attributed to the decline in lymphopoiesis with increasing agc and the dramatic decline of the pre B cells (Johnson et all, 2002). The present work revealed that the lymphocyles exhibited dilated cisterns of rough endoplasmic reticulum with detached ribosome. Some lymphocytes exhibited proliferation of the rough endoplasmic reticulum. Image analysis of the feulgen blue stained sections of the spleen of senile mice which received interferon revealed significant increase in population of lymphoytes at $S$ and $\mathrm{G}_{2}$ phases if the ccll ycle. On the other hand lymphocytes at $\mathrm{G}_{1}$ phase were significantly reduced than scrike splecn. No lymphocyles could be detected at $G_{n}$ phase. These changes were issociated with significant increase in DNA content of lymphocyles at $\mathrm{G}_{1}$ an $S$ priases.

Aging usually increases the incidence of arrest of lymphocytes and decreases proliferation of lymphocytes. The lack of lymphocytic proliferation in aged micc 
could be due to several factors including the diminished lymphoproliferative effects of neuropeptide $Y$ with aging (Medina et al., 2000). It could also be attributed to the less supportive function of aged bone marrow to the proliferation of splenic B cells to plasma cells (Han et al., 2003). Reduced proliferative capacity of both $T$ and $B$ cells could be a result of telomere shortening and end-to-end chromosomal fusion with aging (Blasco, 2002). However, in the present study it seemed thet interferon was capable of increasing the proliferative index of existing lymphocytes in aged mice and enhancing the presence of numerous lymphocytes in the active phases of cell cyles.

In conclusion, interferon increased the activation and proliferation of lymphocytes in adult mice. Aged mice exhibited marked degenerative changes. However, on administration of interferon, though the spleen showed distorted architecture and areas of depletion, yet existing lymphocytes manifested signs of proliferation that might allow interferon to achieve its immuno modulatory functions.

\section{SUMMARY}

Interferon has proved to be effective in treatment of chronic viral hepatitis and a wide variety of autoimmune discases. The present study aimed to investigate the effects of interferon alpha on the lymphoid tissue of the spleen of adult and aged mice. Following subcutaneous administration of interferon to adult mice for three months, the spleen exhibited prominent white pulp encroaching on the regressed red pulp. The zoncs of the white pulp were amalgamated together with indistinct boundarics forming a confluent mass of lymphocytcs. Ultrastructural examination clarified that the lymphocytes manifested signs of mitosis and marked proliferation of the rough endoplasmic reticulum. Other lymphocytes had euchromatic nuclei, dilated cisterns of rough endoplasmic reticulum, numerous milochondria and scattered ribosomes. DNA analysis revealed significant increase in percentage of lymphocyte at $\mathbf{S}$ and $G_{2}$ phases of cell cycle associated with significant decrease in percentage of cells at $G_{1}$ phase. DNA content was significantly increased.

The spleen of senile mice presented regressed white pulp. Marked depletion of lymphocytes was noticed in both red and whitc pulps. Ultrastructural stuies revealed vacuolar cytoplasmic degeneration, pyknotic nuclei and cytoplasmic blebs in the lymphocytes. Although the majority of lymphocytes were at $G_{1}$ and $S$ phases of cell cycle yet there was significant increase in percentage of $G_{0}$ cells with significant decrease in its DNA content. 
Administration of interferon to senile mice for three months revealed distorted architecture. The spleen showed areas of depletion in white pulp and vacuolation in red pulp. However, the existing lymphocytes did not exhibit signs of apoptosis or pyknosis. Ultrastructural examination revealed dilated cistems of rough endoplasmic reticulum. Other lymphocytes showed proliferation of the rough endoplasmic reticulum. The majority of lymphocyte were at $S$ and $G_{2}$ phase and were significantly increased than in senile spleen. The percentage of lymphocytes at $G_{1}$ phase was significantly decreased. The mean value of DNA content of $G_{1}$ and $S$ phases was significantly increased.

\section{REFERENCES}

1. Baer, M.R.; Ozer, H. and Foon, K. (1992) : Interferon \& therapy during pregnancy in chronic myelogenous leukemia and hairy cell leukemia. British D. of Haemotol., (81) : 167 - 169.

2. Blasco, M.A. (2002) : Immunosenescence phenotype in the telomerase knock out mouse. Springer Semin. Immunopathol., 24 (1) : $75-85$.

3. Bose, S.; Chowdhry, V.P.; Saxena, R, and Kucheria, K. (1997) : Lymphoid blast crisis during complete cytogenic remission following interferon alpha and hydroxyurca therapy. Acta Hematol., 98 (3) : 155 - 159.

4. Bosio, E.; Cluning, C.L. and Beilharz, M.W. (2001) : Low dosc orally administered type I interferon reduces splenic B cell number in mice. J. Interferon Cytokine Res., 21 (9) : 721 - 728.

5. Cabelof, D.C.; Raffoul, J.J.; Yanamadala, S.; Ganir, C.; Guo, Z, and Hey Dari, A.R. (2002) : Attenuation of DNA polymerase beta dependent base excision repair and increased DMS induced mutagenicity in aged mice. Mutat. Res., $500(1-2): 135$ - 145.

6. Daiely, R.W.; Eun, S.Y.; Russel, C.E. and Bogel, L.A. (2001) : B cells of aged mice show decreased expansion in response to antigen but are normal in effect or function. Cell - Immunol., 214 (2) : 99 - 109.

7. Duchatelle, V.; Marcellin, P.; Giostra, E.; Bregeoud, L.; Poutea., M.; Boyer, N.; Auperin, A.; Guernets, E.S.; Hemin, D. and Degott, C. (1998) : Changes in liver fibrosis at the end of alpha interferon therapy and 6 to 18 months later in patients with chronic hepatitis $\mathrm{C}$. Quantitative assessment by a morphometric method. J. Hepatol., 29 (1) : 20 - 28. 
8. Faton-Bassirie, A.S.; Mandik-Nayak, L.; Seo, S.J.; Madaio, M.P.; Canero, M.P. and Erikson, J. (2000) : Alterations in splenic architecture and the localization of anti double stranded DNA B cells in aged mice. Int, Immunol., 12 (6) : $915-926$.

9. Eguchi, D.; Hiroishi, K.; Ishil, S. and Mitamura, K. (2003) : Interferon alpha and interleukin - 12 gene therapy of cancer - Interferon alpha induces tumor specific immune responses while intcrleukin 12 stimulates non-specific killing. Cancer Immunol. Immunother., 52 (6) : 378 - 386.

10. EI Sokkary, G.H.; Reiter, R.D. and Abdel Chaffar, S.R. (2003) : Mclatonin supplementation restores cellular thymic lymphocytes of old rats, Neuroendocrinol lett., 24 (3) : 215 - 223.

11. Elliott, M.A. and Tefferi, A. (1997) : Interferon alpha therapy in polycythemia vera and essential thrombocythemia. Semin. Thromb. Hemost., 23 (5) : 463 - 472.

12. Han, S.; Yang, K.; Ozen, Z.; Peng, W.; Marinova, E.; Kelsoe, G. and Zheng, B. (2003) : Enhanced differentiation of splenic plasma cells but diminished long lived high affinity bone narrow plasma cells in aged mice. J. Immunol., 170 (3) : $1267-1273$.

13. Hiramatsu, N.; Hyashi, N.; Kasahara, A.; Hagiwara, H.; Takehara, T.; Haruna, Y.; Naito, M. and Kamada, T. (1995) : Improvement of liver fibrosis in chronic hepatitis $\mathrm{C}$ patients treated with natural interferon alpha. J. Hepatol., 22 (2) : $135-142$.

14. Howel, K.F.; Campo, M.F.; Mahjied, T.; Colemen, C.; Prokopenko, N. and Piggs, J.E. (2003) : Impact of aging upon DBA / 2JB cells. J. Immunol., 207 (2) : $95-103$.

15. Johnson, K.M.; Owen, K. and Witte, P.L. (2002) : Aging and developmental transitions in the B all lineage. Int. Immunol., 14 (11): $1313-1323$.

16. Junqueira, L.C. and Carneiro, J. (2003) : Basic Histology Text and Atlas Lange Medical Books / Mc. Graw - Hill. Middle East Edition - "tenth edition" P. $60-67$, P. $265-290$.

17. Kaserer, K.; Fiedler, R.; Steindl, P.; Muller, C.H.; Wrba, F. and Ferenci, P. (1998) : Liver biopsy is a useful predictor of reponse to interferon therapy in chronic hepatitis C. Histopathol., (32) : 454 - 461.

18. Kim, H.T.; Stoica, G.; Bazer, F.W. and Ott, T.L. (2000) : Interferon TauInduced hepatocyte apoptosis in sheep. J. Hepatol, 31 (6) : 1275 - 1284.

19. Kleiner, D.; Dibisceglie, A.M.; Axiotis, C.A. and Hoofnagle, J.H. (1993) : Prolonged alpha interferon therapy for chronic delta hepatitis effect on liver histopathology. Prog. Clin. Biol. Res., 382: 365 - 371. 
20. Lamers, C.B. (1990) : Concluding remarks. Interferon therapy of diseases of the liver and gastrointestinal tract. Scand. J. Gastronterol. (Suppl.). $178: 119-121$.

21. Manabe, N.; Chevallir, M.; Chossogros, P.; Cousse, X.; Guerret, S.; Trépo, C.H. and Grimoud, J.A. (1993): Interferon $a_{25}$ therapy reduces liver tibrosis in chronic non A non B hepatitis : A quantitative histological evaluation. J. Hepatol., 18 (6) : $1344-1349$.

22. Martin, P.; Del Hoyo, G.M.; Anjeure, F.; Arias. C.F.; Vargas, H.H.; Fernandez, 1.; Parrillas, V. and Ardavin, C. (2002) : Characterization of a new subpopulation of mouse CD8 alpha+ B $220+$ dendritic cells endowed with type 1 interferon production capacity and tolerogenic potential. Blood. $100(2): 283$ 390.

23. Mazzoran, L.; Tamaro, G.; Mangiarotti, M.A.; Marchi, P.; Baracetti, S.; Gerini, U.; Fanni Cannelles, M.; Zorat, F. and Pazzatto, G. (1998) : Effect of interferon therapy on fibrosis serum markers in HCV-positive chronic liver diseasc. Envr. J. Gastrocnterol Hepatol., 10 (2) : 125 - 131.

24. Media, S.; Del Rio, M.; Hernanz, A. and Dela Fuenta, M. (2000) : Age relat* ed changes in neuropeptide $Y$ effects on murine lymphoproliferation and interleukin-2 production. Peptides, 21 (9) : 140,3 - 1409.

25. Merle, P.; Levy, R.; Vitvitsk, L.; Chevallier, M.; Buendia, M.A. and Trepo, G. (1997): Ffficacy ol interferon alpha in primary prevention of prencoplastic lesions in a transgenic in murine model of hepatocellular carcinoma related to the interaction between word chuck hepatitis viruses and c-myconcogene. Gasteroenterol. Clin. Biol., $21(6$ - 7) : 4.59 - 465.

26. Montoya, M.; Schiavoni, (;.; Matter, F.; Gresser, I.; Belardelli, F.; Borrow, P. and Tough, D.F. (2002) : Type 1 interferon produced by dendritic cells promote their phenotype and lunctional activation. Blood, 99 (9) : 3263 - 3271.

27. Moreno, M.G. and Muriel, P. (1995) : Permission of liver fibrosis by interferon alpha 2b. Biochem. Pharmacol., 50 (4) : 515 - 520 .

28. Muriel, P. (1996) : Alpha interleron prevents liver collagen deposition and damage induced by prolonged bile duct obstruction in the rat. J. Hepatol., 24 (5) : 614 -621 .

29. Murphy, W.D.; Keller, J.R.; Harison, G.L.; Young, H.A. and Bongo, D.L. (1992) : Interleukin 2 - activated natural killer cells can support hematopoiesis in vitro and promote marrow engraftment. Blood. 80 (3): 670 - 671 .

30. Ono, K.; Sata, M.; Mura shima, S.; Fukuizumi, K.; Suguki, H. and Tanikawa, K. (1996) : Biological responses to administered interieron in alcoholics. Alcohol Clin. Exp. Res., 20 (9) : 1560 - 1563. 
31. Otely, C.C. and Zitelli, J.A. (2000) : Review of sentinel lymph node biopsy and systemic interferon for melanoma. Promising but investigational modalitie. Derematol. Surg., 26 (30) : 177 - 180.

32. Pabst, R. and Westermann, J. (1994) : Which steps in lymphocyte recirculation are regulated by interferon gamma. Res. Immunol, 145 (4) : 289 - 294.

33. Ruuth, K.; Carlsson, L.; Hallberg, B. and Dundgren, E. (2001) : Interferon alpha promotes survival of human primary $B$ lymphocytes via phosphatid linositol 3 - kinase. Biochem. Biophys. Res. Comun., 284 (3) : 583 - 586.

34. Salazar, T.P.; Ishikawa, R. and Biron, C.A. (1996) : N.K. cell trafficing and cytokine expression in splenic compartments after IFN induction and viral infection. J. Immunol., 157 (7) : 3054 - 3064.

35. Schindowski, K.; Leutner, S.; Kressmann, S.; Eckert, A. and Muller, W.E. (2001) : Age related increase of oxidative stress induced apoptosis in mice prevention by Ginkgo biloba extract. D. Neural. Transm., 108 (8 - 9) : 969 - 978.

36. Singh, B.; Oh, T.L.; Bazart, F.W. and de la Concha Bermejillo, A. (1998) : Structural responses of pulmonary intravascular macrophages in lenti virusinfected and or recombinant ovine interferon - tan - treated lambs. Anat. Rec., 251 (4) : 472 - 485.

37. Steinger, B. and Van der Meide, P.H. (1993) : High dose interferon gama alters the distribution of $B$ lymphocytes and macrophages in rat spleen and lymph nodes. J. Immunol, 78 (3) : 461 - 467 .

38. Suzuki, D.; Sakai, D.; Okada, A.A.; Takada, E.; Msui, M. and Mizuguchi, D. (2002) : Oral administration of interferon suppresses experimental auto immune uveoretinitis Graefes. Arch. Clin. Exp. Ophthalmol., 240 (4) : 314 - 321.

39. Theocharis, S.E.; Margeli, A.P.; Skaltsas, S.D.; Skopelitou, A.S.; Mykoniatis, M.G. and Kittas, C. (1997) : Effect of interferon $\alpha_{2 \mathrm{~b}}$ administration on rat liver regeneration after partial hepatectomy. Digest. \& Sci., 42 (9) : 1981 1986.

40. Toliou, T.; Stravoravdi, P.; Polyzonis, M. and Vakalikos, J. (1996) : Natural killer all activation after interferon administration in patients with metastatic renal cells carcinoma : an ultrastructural and immunhistochemical study. Eur. Urol., 29 (2) : $252-256$.

41. Watanabe, K.; Watanabe, M.; Maruoka, H.; Amino, N. and Iwatani, Y. (2001) : Increase of CD5 (+) B cells during adolescence in female mice. Mech. Ageing Dev., 122 (15) : 1787 - 1795. 
42. Woods, J.A.; Ceddia, M.A.; Zack, M.D.; Lowder, T.W. and Lu, Q. (2003) : Exercise training increase the naive to memory $\mathrm{T}$ cell ratio in old mice. Brain. Behav. Imun., $17(5): 384-392$.

43. Yoo, Y.K.; Gavalar, J.B.; Chen, K.; Whiteside, T.L. and Van Thiel, D.H. (1990) : The effect of recombinant interferon alpha on lymphocyte subpopulations and HLA. DR expression on liver tissue of HBV positive individuals. Clin. Exp. Immunol., 82 (2) : 338 - 343. 


\section{الملخص العريى

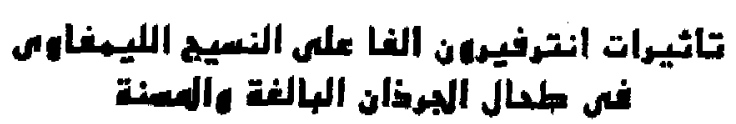

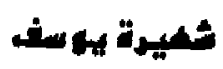

تسم التشريع - كلية الطب - جامعة عين شمس

أثبت عقار الانترفيربن فاعلية فى علاج الالتهاب الكبدى الفيرعبسى المزمن

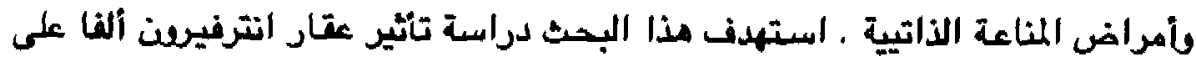

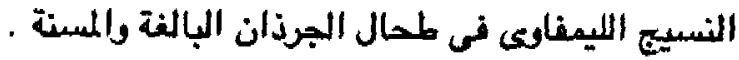

عقب إعطاء الانترفيرون تحت الجلد لمدة ثلائة شهـر للفئران البـالنة ـ أظهر

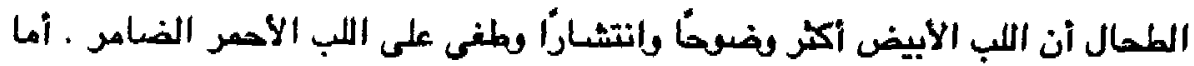

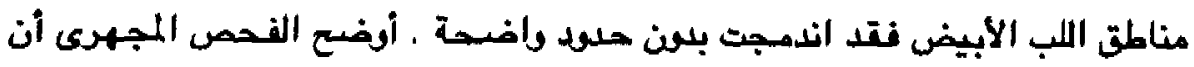

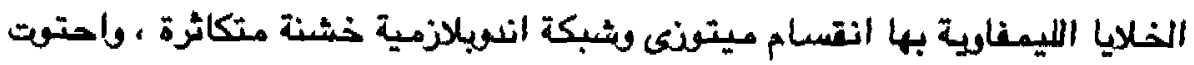

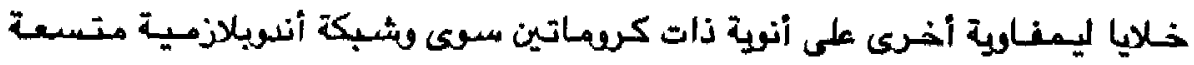

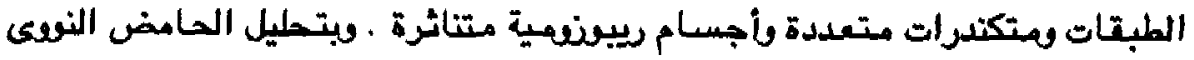

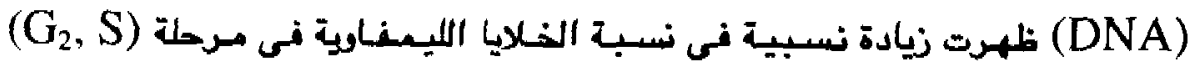

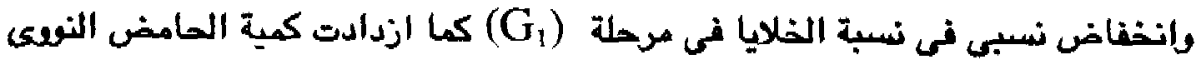
نسبيً

أظهر طحال الفأر المسن خمعل في اللب الابيض وظمهرت مناطق مغرغة في اللب

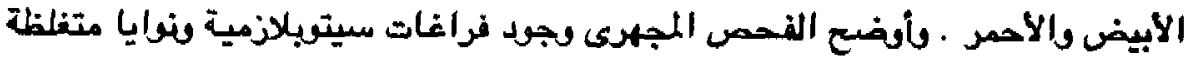
، وفتاعات أو نغطات سيتربلازمية فى الخلايا الليمارية ـ وبالرغم من أن معظم الخلايا

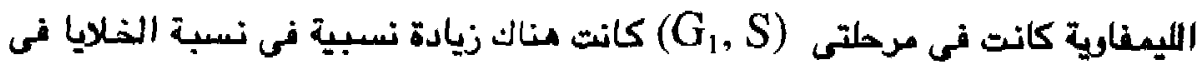

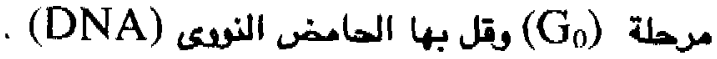


عقب إعطاء عتار الانترنيرسن للجرذان المسنة تبين أن الهيكل العام للطحال

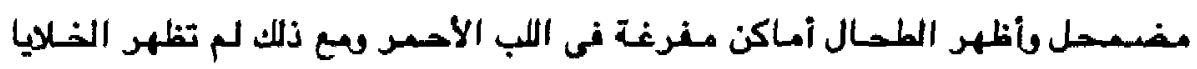

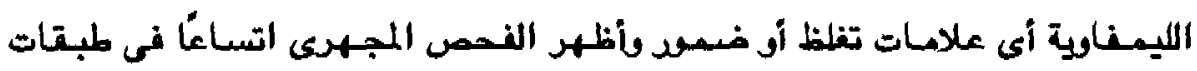

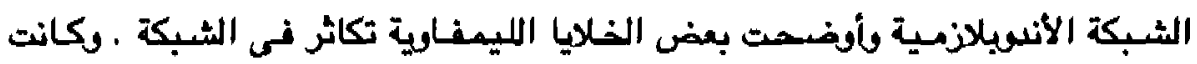

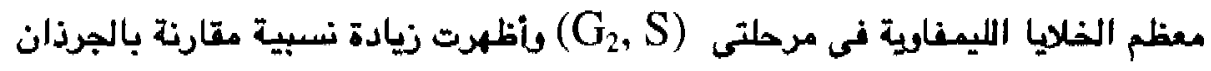

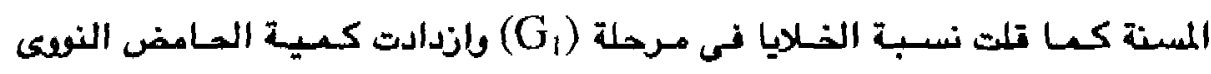
(GNA)

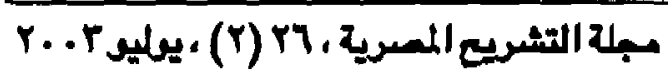

